\title{
Virkeligheder og religionshistorie: En introduktion til ontologier ifølge Philippe Descola
}

\author{
HANS J. LUNDAGER JENSEN
}

\begin{abstract}
ENGLISH SUMMARY: A presentation of Philippe Descola's model of four ontologies (animism, totemism, analogism, and naturalism) and six forms of attachment (gift, exchange, etc.) and an argument for their relevance for the academic study of religion. The four ontologies overlap partly with Robert Bellah's stages of cultural-religious evolution: Animism and totemism dominate in tribal religions, analogism in archaic and post-axial religions, naturalism (or natura-culturalism) in the post-Christian modernity.
\end{abstract}

DANSK RESUME: En præsentation af Philippe Descolas model over fire ontologier (animisme, totemisme, analogisme og naturalisme) og seks relationsformer (gave, bytte m.m.) med argumentation for deres relevans for religionsvidenskaben. De fire ontologier relateres til Robert Bellahs religionshistoriske stadier: Animisme og totemisme dominerer $i$ tribale religioner, analogisme $i$ arkaiske og post-aksiale religioner og naturalisme i den post-kristne modernitet.

KEYWORDS: Philippe Descola; ontologies; animism; totemism; analogism; naturalism; Robert Bellah; gift; history of religion

\section{Indledning: Baggrundsinformation og virkelighedsopfattelse}

Alle religioner forudsætter en virkelighedsopfattelse. Ofte er den mere eller mindre stiltiende forudsat, men kan skimtes $\mathrm{fx}$ i den baggrundsinformation der gives i en fortælling i og med fremstillingen af fortællingens hovedtemaer. I fortællingen om Sodomas ødelæggelse i Gen 19 er det et eksplicit tema at guddommen Jahve har sendt to engle til byen for at prøve befolkningens moralske habitus, at de bliver groft behandlet af den lokale befolkning, men gæstfrit modtaget af Lot, Abrahams nevø som derfor 
bliver reddet ud af byen før den overdynges af himmelsk svovl og ild. Baggrundsinformationen her er at der eksisterer engle. Fortællingen forudsætter altså en indforståethed med eksistensen af engle og en omtrentlig forventning om hvad slags væsener de er og hvad de er i stand til at gøre. Hvis der er en overraskelse på dette punkt i fortællingen, er det fx ikke at de udfører et mirakel, men måske at miraklet består i at de slår den mandlige befolkning med blindhed. I et sådant tilfælde vil det være bedre at tale 'antagelse af eksistensen af engle' end om 'tro' på dem. Set udefra, fx fra et nutidigt blik, kan der dårlig tales om andet end netop en 'virkelighedsopfattelse'. Men for de mennesker der levede i den verden hvor legenden om Sodoma blev fortalt, var der ikke tale om en 'opfattelse', men om virkeligheden slet og ret.

Den ikke-eksplicitte baggrundsinformation er ofte mere interessant for religionshistorien end den eksplicitte information, 'forgrundsteksten', $\mathrm{fx}$ at det var til netop Sodoma, englene kom, og at det var netop Lot der gjorde sig fortjent med sin gæstfrihed. Men da virkelighedsopfattelsen ikke ekspliciteres, må den rekonstrueres ud fra de spor som fx en fortælling og dens kontekst indeholder. I GT er engle tydeligvis en slags væsener, for de kan handle, kommunikere og påtage sig menneskelig skikkelse. De hører tilsyneladende til i himlen; men der siges intet om hvordan himlen er indrettet, og der er kun få antydninger af hvad de foretager sig i dér. Formodentlig har forestillingerne om dem været nogenlunde så uklare som det indtryk, nutidsmennesker får ved at læse i GT.

I en given religions virkelighed indgår eksistensen af kulturelt specifikke elementer, $\mathrm{fx}$, som her, engle, byen Sodoma og guddommen Jahve. Men der indgår også elementer der ikke er specifikke på samme måde, fx eksistensen af byer og en himmelsk guddom. Disse mere grundlæggende antagelser er naturligvis ikke særlige for GT; de findes i mange andre arkaiske religioner, ikke kun oldtidens nærorientalsk-mediterrane som mesopotamisk, egyptisk og græsk religion. Men der er også mange religioner som har helt andre virkelighedsopfattelser, fx tribale religioner, der hverken har byer eller himmelske guddomme af den gammeltestamentlige slags. Det må derfor være en religionshistorisk opgave at rekonstruere de forskellige virkelighedsopfattelser der er fælles for typer af religioner, såsom tribale og arkaiske.

\section{Descola, dyr, planter og mennesker}

I artiklen her vil jeg præsentere og diskutere Philippe Descolas forslag til definition af fire fundamentale virkelighedsopfattelser, 'ontologier', som de er fremlagt i hans bog Par-delà nature et culture fra 2005. ${ }^{1}$ Dertil kommer en kortere fremstilling af hans bud på seks grundlæggende former for relationer imellem aktører: gave, prædation, udveksling, frembringelse, beskyttelse og overlevering. Jeg vil argumentere for at ontologierne og relationsformerne kan være til så stor nytte for religionsvidenskaben at de bør indgå i dens basale begrebsinventar.

1 Engelsk oversættelse Beyond nature and culture, 2013, som vil jeg i det følgende vil referere til. Modellen har Descola skitseret mange steder, bl.a. Descola 2010; 2011; 2014; Descola \& Charbonnier 2014. 
Philippe Descola er en fransk antropolog i den strukturalistiske retning (han er kritisk - elev af bl.a. Claude Lévi-Strauss ${ }^{2}$ ), hvis vigtigste feltarbejde blev foretaget blandt Achuar-folket, en del af Jivaro-kulturen i grænselandet imellem det østlige Ecuador og det nordlige Peru. Achuar er en ikke-statslig, skriftløs kultur der økonomisk er baseret på 'tropisk flytteagerbrug' og jagt. Af let forståelige grunde har Achuar-mennesker et indgående kendskab til dyr og planter; de er dels, som føde, det nødvendige livsgrundlag, dels potentielt farlige og skadelige (som rovdyr, giftige planter). Samtidig er deres forståelse af hvad dyr og planter egentlig er, ekstremt forskelligt fra den vestligt-nutidigt dannede og uddannede antropologs forståelse. Meget kort fortalt kan man sige, at den 'vestlige' antropolog (som repræsentant og udsending for en udbredt nutidig virkelighedsforståelse overalt på kloden) normalt vil have et begreb dels om 'natur' i betydningen: alt det der omfatter dyrene, planternes og tingenes verden, dels om en særligt menneskelig virkelighedssfære, der traditionelt kan kaldes 'ånd' eller, mere nutidigt, 'kultur' eller 'bevidsthed'. Men selv om et Achuarmenneske registrerer de samme fænomener som moderne mennesker, såsom brøleaber og maniokplanter, kan disse fænomener ikke siges at udgøre en 'natur' som noget der er essentielt forskelligt fra en menneskelig virkelighed. Også en Achuar vil se forskelle imellem mennesker, brøleaber og maniokplanter; men forskellene vil forstås fundamentalt anderledes. ${ }^{3}$

Ud fra denne kollision i virkelighedsforståelser har Descola udviklet en model for eller et skema over hvordan kulturer typisk forstår og har forstået virkeligheden. Achuar-virkeligheden er ikke en lokal ejendommelighed; den er tværtimod af en type der kan findes på flere kontinenter. Men den er ikke den eneste virkelighed der adskiller sig fra den moderne.

\section{Ontologier og religionsvidenskab}

Descolas model går ud fra - og er et langt stykke koncentreret om - relationen imellem mennesker på den ene side, dyr og planter på den anden (og altså ikke fx om eksistensen af og evt. relationerne til ånder, guddomme, døde og lignende). Ikke desto mindre er den i høj grad relevant for religionsvidenskaben. Dels vil en forståelse og en beskrivelse af en religion som sagt altid forudsætte en forståelse af dens antagelser om virkelighedens beskaffenhed (i praksis: navnlig hvor den afviger fra moderne antagelser). Dels kan dyr og planter i visse religioner indtage de pladser og funktioner, som i andre

2 Sidestillet med Lévi-Strauss som inspirationskilder fremhæver Descola selv navne som Pierre Bourdieu, Michel Foucault, Georges Dumézil (Descola 2010, 212; Descola og Charbonnier 2014, 110f.). Blandt aktuelle inspirationskilder og diskussonspartnere optræder hyppigt Tim Ingold, Eduardo Viveiros de Casto og Bruno Latour (ibid., 205. 297-300).

3 Ifølge Descola $(2010,209)$ har Achuar hverken religion eller ritualer. De er formentlig på dette punkt ikke typiske for Amazon-kulturer (et helt andet eksempel udgør Kalapalo, refereret i Bellah 2011, 138-146). Men han definerer ikke hvad han forstår ved 'religion'. Dels har Achuar shamaner og derfor shamanistiske ritualer (Descola 1989, passim), dels er der så mange forbindelseslinjer imellem animistiske og arkaisk-religiøse forestillinger at animisme efter min mening uproblematisk også kan forstås som en religion. 
religioner indtages af guddomme. Dels vil alle religioner indeholde en forståelse af dyr og planter: som selvstændige væsener, som medier for eller attributter til ånder og guder, eller som del af den opståede, skabte eller foreliggende verden ved siden af mennesker og resten af den umiddelbare virkelighed. Og endelig kan Descolas model omfatte virkelighedsforståelser i arkaiske religioner. Disse er af særlig betydning for religionsvidenskaben, for det er i disse at 'religion' i den mest umiddelbare betydning af ordet er udviklet - 'religion' i betydningen 'antagelsen af eksistensen af guddomme og af nødvendigheden af at måtte interagere med disse'. ${ }^{4}$

Jeg vil derfor relatere ontologierne ifølge Descola til Robert Bellahs model for en generel religionshistorie, som ved flere lejligheder er præsenteret og diskuteret her i Religionsvidenskabeligt Tidsskrift. ${ }^{5}$ Begge modeller har meta-historiske ambitioner. De to modeller har forskellige formål, for Descolas model går ud fra mulige virkelighedsopfattelser, mens Bellahs går ud fra historiske samfundsformationer. Men de kan meningsfuldt relateres og betragtes som gensidige supplementer. Forud herfor skal der dog gives nogle begrebsmæssige forklaringer.

\section{Begreber, teori og metode}

'Ontologi', etymologisk 'læren om det værende', var i græsk filosofi nærmest ensbetydende med metafysik, til forskel fra andre filosofiske hovedgrene, såsom læren om logik, erkendelse og etik. Fra og med senmiddelalderen begynder ontologi at miste betydning til fordel for epistemologi (erkendelseslære). Hvis virkeligheden kun kan forstås på forståelsens præmisser, bliver det mere relevant at forstå forståelsen selv. Et berømt og ekstremt eksempel er Kants berømte begreb om virkeligheden som ‘Ding an sich'. Den antages at eksistere, men kan ikke kendes i sig selv, kun igennem menneskelig forståelse som 'Ding für uns'. Menneskelig erkendelse placerer virkeligheden som størrelser i tid og rum og underlagt årsagssammenhænge. Måske er virkeligheden også sådan, og måske er den helt anderledes. Men det kan vi mennesker ikke vide, fordi alt hvad vi ved, forudsætter sådanne tankekategorier som tid, rum og årsagssammenhænge. Og dette gælder også for naturvidenskabelig erkendelse. Naturvidenskab ser og måler og udregner; men det forudsætter øjne og måle- og regneprocedurer, som er menneskelige produkter. Det kan godt være at det i praksis ikke gør nogen forskel, om virkeligheden faktisk er sådan som den måles og udregnes. Men filosofisk gør det en stor forskel.

4 Altså religion i James Georges Frazers berømte og misvisende definition: tro på magter højere end mennesker og et forsøg på at forsone eller glæde dem (Frazer 1922, 65f.) - berømt fordi den formentlig omtrentlig svarer til nutidig, dagligsproglig brug og er nogenlunde dækkende for arkaisk religion, misvisende fordi den ikke dækker hverken religioner i tidligere kulturformer eller religioner fra og med det aksiale snit (frelses- og forløsningsreligioner).

5 Robert Bellahs religionshistoriske periodisering er blevet introduceret og diskuteret i tidligere artikler her i Religionsvidenskabeligt Tidsskrift. I lærebogen Andre verdener (Fibiger \& Lundager Jensen, eds. 2021) er der to forslag til en videretænkning og anvendelse af Bellahs teori, dels Anders Klostergaard Petersens (i kapitlet om religiøse roller), dels min egen (i kapitlet med oversigt over religionshistorien). 
Traditionel filosofisk ontologi forudsatte imidlertid at der kun gives én virkelighed; opgaven var at beskrive den bedst muligt, fx om hvorvidt noget værende eksisterer i sig selv eller er forårsaget af noget andet eller om det er simpelt eller sammensat. Men den antropologiske erfaring er at der kan være store forskelle på de virkeligheder som mennesker fra forskellige kulturer lever i. For at tage et eksempel fra et andet domæne, som Descolas analyse som sagt ikke specielt angår. Man kan fx gå ud fra at der findes engle, dæmoner, guddomme eller omkringgående døde, også selv om man kan være skeptisk over for udsagn om deres bestemte tilsynekomster eller magtmanifestationer. Eller man kan antage eksistensen af én guddom, men ikke af ånder eller døde, som fx i varianter af nutidig kristen teologi. Eller man kan antage eksistensen af dem alle: guder, dæmoner osv., som fx i mesopotamisk religion. Den antropologiske erfaring af alternative virkelighedsforståelser kan altså suppleres med en historisk. Flertallet af mennesker i Vesteuropa for bare to-tre hundrede år siden havde en anden ontologi end de fleste mennesker i dag. I den dominerende ontologi i dag har sådanne væsener kun status som forestillinger folk kan have i deres hoveder; de findes ikke i 'den ydre verden' - de antages altså at høre til bevidstheden, ikke til virkeligheden.

\section{Naturalisme: Natura-kulturalisme}

Den dominerende nutidige ontologi (også for religionsvidenskaben) kan kaldes 'naturalistisk' i betydningen at der findes en 'natur', dvs. et selvstændigt domæne, med en materiel basis, som er reguleret af immanente lovmæssigheder; 'naturen' er styret af 'naturlove'. Til dette domæne hører grundstoffer, mineraler og organismer, fra de ældste mikroorganismer op til og med menneskenes kroppe. Da naturen består af de samme grundstoffer og regeres af de samme principper, kan de også beskrives af én samlet videnskab, naturvidenskaben (der på engelsk ofte betragtes som videnskaben slet og ret, 'science', i modsætning til bl.a. 'humanities', der ikke hører til videnskaben). Sundhedsvidenskab er her kun et selvstændigt felt af praktiske grunde. Ved siden af 'naturen' er der så et kaotisk domæne af specifikt menneskelige fænomener: sprog, emotioner, forestillinger, symboler, kulturer, normer, samfundsindretninger, retssystemer, æstetik i mange udgaver (beklædning, musik, dans, maleri, skulptur, litteratur osv.) og, naturligvis, religion. Dette domæne er ikke materielt, det er ikke styret af naturlove og det kan ikke beskrives af fysik, kemi og biologi. Men det kan godt beskrives, i hvert fald til en vis grad, hvis der er en så tilpas grad af regelmæssighed at det kan betragtes som en art foreliggende genstand, en 'ting', som Durkheim udtrykte det. ${ }^{6}$ Man kan fx beskrive et sprogs struktur, en bestemt samfundsindretning eller en bestemt modstrømning. Hvad dette ikke-naturlige domæne skal kaldes, hersker der ikke konsensus om. Émile Durkheim foreslog at kalde det 'samfund' og viden om det for 'sociologi'. I det omfang domænet, eller dele af det, overhovedet skal kunne beskrives,

6 I Durkheim, Les regles de la méthode sociologique 1895 (p. 15 i 1997-udgaven; i dansk oversættelse: Durkheim 2000, 58). 
må det besidde regelmæssigheder der kan beskrives statistisk eller med modeller; og regelmæssigheder forudsætter at grupper af mennesker, dvs. 'samfund', er involveret. I 1600-1700-tallets 'oplysning', forud for sociologiens opkomst, ville man typisk forstå dette ikke-naturlige felt som noget sjæleligt eller åndeligt, altså noget subjektivt, og man ville forankre det i det individuelle menneske. I nutiden, efter den tidlige sociologis, hhv. antropologis, mellemkomst, vil det være mere nærliggende at betragte domænet kollektivt, som noget mennesker formidler til hinanden og lærer af hinanden, dvs. som 'kultur' (i antropologisk forstand, ikke i betydningen 'højkultur', 'borgeligæstetisk dannelse' eller lignende). Derfor bør betegnelsen for den nutidige, dominerende ontologi, 'naturalisme', forstås som en praktisk forkortelse af det mere dækkende 'natura-kulturalisme'.

Naturalismen er altså en dualisme i betydningen at den forudsætter at der gives to selvstændige domæner. Hvor grænsen mere præcist går imellem natur og kultur, er et åbent og stadigt diskuteret spørgsmål. I udgangspunktet ligger grænsen ikke imellem det ikke-menneskelige og det menneskelige slet og ret, men inde $i$ kategorien 'menneske'. Menneskelige kroppe hører til naturens domæne. Men menneskekroppe er også bærere af kultur (tanker, forestillinger, normer) på en måde som det er svært eller umuligt at forestille sig på anden måde end at ved at det er noget der er 'inde i' dem. Traditionelt har man kunne se forholdet som en sjæl eller en ånd inde i kroppen, evt. i et særligt organ (hjertet har været et traditionelt bud, hjernen et typisk nutidigt). Kroppen er dermed en beholder for noget andet der ikke er krop, og det er dette andet der giver menneskets dets særlige værdighed og rettigheder, pligter og ansvar. Sten, planter og dyr derimod har ikke værdighed, rettigheder og ansvar fordi de ikke har en sjæl / ånd / bevidsthed / kultur. Derfor kan mennesker være part i en retssag, fordi de kan gøres ansvarlige for deres handlinger. Middelalderens eksempler på retssager imod dyr, der er blevet beskrevet i nyere undersøgelser, virker derimod komiske eftersom alle jo ved at man ikke kan gøre dyr ansvarlige for deres handlinger, eftersom de ikke har moralske normer. Men denne 'viden' skyldes nutidens natura-kulturalistiske ontologi. ${ }^{7}$ For naturalister er der ingenting inde i et dyr, en plante, en sten, et regnvejr eller en stjerne, andet end det materiale som disse masser er gjort af.

Det er uklart hvor meget af det der er resultatet af menneskers bevidsthed, kan siges $i k k e$ at høre til naturens domæne. En konsekvent 'materialistisk' tænkning vil forklare 'kulturelle' (eller 'mentale') fænomener som reelt determineret af 'naturlige' faktorer. Dermed udstrækkes naturens domæne til det hele; den natura-kulturalistiske dualisme erstattes her med en naturalistisk monisme. I modsat retning peger tendensen til at antage at træk der traditionelt antages at være unikt menneskelige, også gælder for dyr.

I sin mest bastante udgave vil ikke-menneskelige størrelser betragtes som grundlæggende ens, dvs. som materialitet. Der er i så fald ingen væsentlig forskel imellem en sten, et træ og en kylling uanset at træet er levende og stenen ikke er. Et træ kan

7 Oversigt: "Medieval Animal Trials", Medievalists.net: https://www.medievalists.net/2013/09/medieval-animal-trials/ (set 2021-03-03). Jf. mere herom i Lars Albinus, “Dyrenes betydning i religion og filosofi" i dette nr. af Religionsvidenskabeligt Tidsskrift. 
fældes fordi man skal bruge tømmeret, og en kylling kan gasses fordi man skal bruge kødet; et menneske derimod har en særstatus og en værdighed, som gør det problematisk eller forbudt at slå det ihjel og spise det. Men det er næsten umuligt ikke at skelne imellem visse dyr og andre, store og små, med og uden pels, mere eller mindre menneskelignede; og de første eksempler er kendt på at visse dyr, særligt menneskeaber, tilskrives rettigheder på linje med mennesker. ${ }^{8}$ Det er heller ikke så ligetil at fraskrive dyr 'kultur'. Selv om hunde kan forstå hinanden over hele kloden, og altså ikke har en kultur som de menneskelige, kan mange dyr udvikle adfærdsformer der transmitteres lokalt, ikke genetisk, og altså er en slags læring, der ikke gælder for hele arten, og som mest nærliggende kan forstås som en slags kultur. ${ }^{9} \mathrm{Og}$ som Bruno Latour har vist i Vi har aldrig været moderne, ${ }^{10}$ er det en fortløbende proces at forsøge at fordele fænomener i et af de to domæner. Selv om sondringen imellem natur og kultur synes enkel og klar, er det i praksis ikke let at bestemme præcis hvad der hører til hvilket domæne. Et af de videnskabelige felter der synes at ligge ubekvemt i spændingsfeltet imellem natur og kultur, synes at være psykologien; hvor meget af dens felt er krop, og hvor meget er bevidsthed? Diskussioner (og kampe) for og imod kognitiv psykologi føres netop hen over naturalismens slugt imellem natur og kultur.

Den normale praksis inden for såvel naturvidenskaben som ikke-naturvidenskabelige områder er at lade hinanden være og dermed også at betragte det andet område som irrelevant og trivielt for ens eget vidensfelt. I kulturvidenskaberne vil det være relevant hvad en gruppe mennesker, ud fra mængden af mulig føde, vælger at spise og hvad de vælger fra; men det er trivielt at de overhovedet har behov for at spise. I naturvidenskaben er det trivielt at forskellige mennesker og kultur har forskellige kulinariske præferencer, fordi det interessante her er stofskifte, fordøjelsesproces og næringsstoffer. Men ikke mindst i antropologiske sammenhænge bliver naturalismens problem akut. I udgangspunktet er der ikke noget problem, så længe en antropolog betragter sin egen ontologi som indiskutabel rigtig. I det tilfælde vil andre ontologier være forkerte: misforståelser, illusioner, fantasmer, naiv og forældet overtro. Tylor og Frazer havde en sådan robust-brutal ontologi. Den 'vilde' (det var deres kategori: 'the savage') havde nok de samme mentale kapaciteter som dem selv; men den vilde havde en illusorisk og naiv forståelse af verden, som videnskaben havde dementeret - fremskridt som forhåbentlig med tiden ville udbrede sig til alle samfundslag. Antropologien i dag har typisk også en moralsk dagsorden. Ud over den rent deskriptive inte-

8 Det første juridiske eksempel på at tilskrive menneskeaber personstatus og dermed fundamentale menneskerettighed (der herefter måske skal sættes i anførselstegn?), skal være en lov på De Baleariske Øer (eng. Wikipedia: “Great Ape Personhood” (set 2021-03-03).

9 Jf. eng. Wikipedia, "Animal Culture" (set 2021-03-03).

10 Latour 2006; fransk 1991. 
resse vil antropologen i felten også ønske at skabe sympati eller agtelse for sine værter. ${ }^{11}$ Det kan være vanskeligt hvis man ikke kan forstå selve deres virkelighedsopfattelse som andet end en naiv illusion. Selve den etnografiske undersøgelsessituations stemning af principiel anerkendelse af det fremmede og den fremmede må fremkalde forbehold over for ens egne forestillinger og principper - der desuden under alle omstændigheder er erkendt selv at være resultat af en historisk og menneskelig mentalitetshistorie. Men hvad der kommer til på den måde, kan også gå igen. Selv Frazer afsluttede sin Golden Bough - lidt overraskende, i forhold til hans ellers typisk selvsikre-scientistiske tone - med at forudse en fremtidig virkelighedsopfattelse som ville overhale den form for videnskab, han selv kendte. ${ }^{12}$

Et stabilt punkt i naturalismen er dog at forskelle i virkelighedsforestillinger netop er det, nemlig forskelle i forestillinger, ikke i virkeligheder. Også Descola hævder ikke andet end at ville prøve at forstå de forskellige ontologier som måder at se virkeligheden på, eller 'en måde at være i verden på' (Descola \& Ingold 2014, 14). Det vil sige at hans beskrivelse af ontologierne forudsætter én af dem, den moderne (som nedenfor skal kaldes naturalisme). Trods talen om en 'ontologisk vending' (jf. Kelly 2014) er det svært at se også Descolas model som andet end i grunden epistemologisk, ikke virkelig ontologisk; under alle omstændigheder vil den være baseret på antagelser om menneskelige og universelle, kognitive evner (Descola 2010; 2010a). Men dette formentlig uopløselige paradoks er en pris værd at betale for en model som dermed til gengæld er ikke kun oplysende, men også kompatibel med normal kulturvidenskab, herunder med normal religionsvidenskab. ${ }^{13}$

Når der med ontologi således menes en virkelighedsopfattelse som findes hos mennesker i bestemte samfund, er ontologi altså beslægtet med et begreb som religionsvidenskaben er mere fortrolig med: Clifford Geertz' begreb om kulturer med hvert deres særlige 'world view'. ${ }^{14}$ Men Descolas begreb om ontologi er 'dybere' eller mere abstrakt end Geertz' verdensbillede. Det er enklest at forstå 'verdensbillede' som en bestemt kulturs forståelse af verden: den egyptiske, den mesopotamiske, den israelitiske, den græske. Her ligger vægten på det unikke, det der adskiller dem, fx om der er mange forskellige, relevante guder eller kun én relevant, om mennesker kan få et godt liv efter døden hvis de balsameres og lægges i kostbare gravkamre, om de bliver fugleagtige skikkelser i et rige under jorden eller blot sover uforstyrret, om guddomme

11 Dette er et punkt hvor der ofte er forskel imellem den antropologiske og den religionsvidenskabeligt-historiske tilgang til deres emner; det har været accepteret i religionsvidenskaben at betragte religiøse mennesker på linje med Tylors og Frazers 'vilde'.

12 Frazer 1922, 932: "as science has supplanted its predecessors, so it may hereafter be itself supplanted by some more perfect hypothesis, perhaps by some totally different way of looking at the phenomena ..."

13 Amazon-antropologen Eduardo Kohn $(2013,10)$ anbefaler ontologi i den descolaske forstand "because of the way it renders ontology plural without turning it into culture: different worlds instead of different worldviews". Forskellen til begreber om kultur og verdensbillede er klare nok, jf. næste afsnit. Men det er nu alligevel nemmest at forstå Descolas kategorier ud fra en naturalistisk basis-dualisme.

14 Således Descola 2013, 309, uden reference til Geertz. 
bosætter sig i statuer der kan vises frem ved festlige lejligheder eller om dette er en urimelig tanke. Et verdensbillede vil altså typisk være en mættet mængde af antagelser om eksistensen af alt muligt. Nu er der også træk i en given kulturs virkelighedsforståelse der ikke er specielt unikke, men fælles for mange andre - i eksemplet her således ikke blot for disse antikt-nærorientalske kulturer, men for mange andre der ikke står i nogen påviselig (eller i det mindste: ikke direkte påviselig) indbyrdes forbindelse, således den gamle indiske, kinesiske og selv mellemamerikanske højkulturer. ${ }^{15}$ Ifølge Descola kan dette niveau indfanges hvis man ser på hvordan mennesker typisk identificerer andre væsener. En - tilstrækkeligt hårdkogt - naturalist vil i princippet identificere stenen, træet og hunden som ting - mindre eller mere komplekse indeni, men uden det der gør mennesker til mennesker, og som er at de er dobbelte: Deres kroppe er beholdere for noget ikke-kropsligt. Alle andre væsener er entydige; de er ikke beholdere, for der er ikke noget andet og mere end krop.

Descolas ontologier er ikke indholdsrige domæner af viden, sådan som Geertz' verdensbillede er. De er skemaer, kvasi-spontane antagelser, som aktiveres i mødet imellem et menneske og et ikke-menneske. En naturalist undersøger fx ikke om der er en sjæl inden i et dyr eller en plante; naturalisten 'ved' på forhånd at det er der ikke. En animist derimod 'ved' ikke om der måtte være en sjæl inden i dyret eller planten; animisten vil overveje det, gå ud fra at det er der formodentlig, eller være sikker på at det er der. Sådanne skemaer forudsætter mere basale kognitivt-psykologiske evner, dispositioner, herunder at kunne skelne imellem jeg og omverden, noget ydre og noget indre, forskelle og ligheder. Disse skemaer er udviklet 'fylogenetisk', altså i løbet af menneskeartens udvikling, og de kan derfor aktiveres af alle mennesker, uanset deres kultur og verdensbillede. Enhver kan altså i princippet reagere som en naturalist eller en animist. Men hvordan skemaerne aktiveres, afhænger af de konkrete omstændigheder som et menneske lever under, hvilke ikke-menneskelige størrelser det typisk konfronteres med og, selvfølgelig, hvordan andre mennesker i dets umiddelbare omverden typisk tænker (Descola 2010; 2010a).

Ontologierne kan altså siges at skydes ind imellem et kognitivt niveau 'under' og et kulturelt niveau 'over'. Det kognitive niveau leverer mulighedsbetingelserne for at skemaerne er til stede, og det kulturelle niveau vil bestemme sandsynligheden for at et eller flere bestemte skemaer aktiveres.

15 Mellemamerikanske højkulturer, hvoraf aztekere og mayaer er de senest tilkomne og almindeligt kendte, betragtes gerne som eksempel på selvstændig kulturel evolution; men der er stemmer der formoder kulturel udveksling hen over Stillehavet: Jett 2017. 


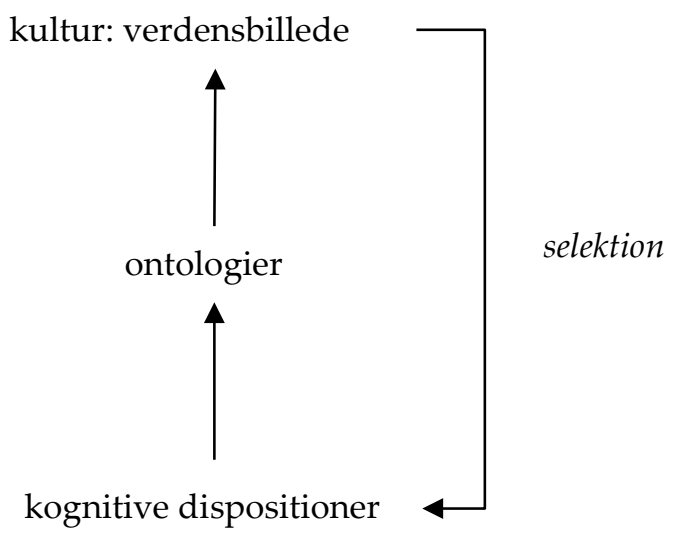

\begin{abstract}
Animisme
Dette er udgangspunktet for Descolas model over ontologier: Hvad forventer man når man står over for noget som ikke er et menneske? Forholdet er tydeligst når dette ikkemenneske er et dyr; for mange dyr ligner unægtelig mennesker på mange måder, med øjne, ører, mund, bevægelse, lyde, behov for føde, trang til forplantning og meget andet som mennesker kender fra sig selv. Ontologi kan derfor også formuleres som typiske 'følgeslutninger' (inferenser), en 'måde at identificere et ikke-menneskeligt væsen på’. Og her begynder Descola med et illustrativt eksempel fra sit eget feltarbejde.

Descolas mandlige Achuar-værts kone bliver bidt af en klapperslange. Descola hjælper med serum og med en beklagelse over denne ulykkelige tilfældighed. Hendes mand derimod mener at klapperslangebiddet formentlig er en berettiget straf over ham og hans familie. Straffen kommer fra en af de vilde dyrs beskytterinder, og den er udløst af at han selv havde fået et nyt haglgevær og for sjov havde skudt løs på en flok uldaber, hvoraf nogle, men flere end han skulle bruge, var dræbt, og andre skamskudt. Aberne havde klaget til deres shaman, som havde klaget til dyrenes beskytter, og hun havde sendt den klapperslange som havde bidt hans kone. Aber er personer, lige som mennesker, forklarer han sin etnografiske tilhører. De, og andre større dyr, er menneskenes slægtninge. De lever som mennesker, de hører hvad mennesker siger. Og de har et socialt liv med hinanden der er lige som menneskenes; de gifter sig med hinanden, taler, går på jagt og danser sammen, lige som mennesker gør. Nogle af dyrene er selvfølgelig farlige, som fx jaguarer, som kan slå mennesker ihjel. Men det gør
\end{abstract}


dem ikke mindre til personer; mennesker kan jo også slå deres egne artsfæller og slægtninge ihjel. ${ }^{16}$

Achuar driver jagt, men den vigtigste føde kommer fra planter, som kvinderne dyrker i haver. Også mange planter er personer med sjæle, og de kan tavst (igennem drømme) kommunikere indbyrdes og med andre væsener. ${ }^{17}$ Mennesker kan til gengæld kommunikere med dyr, planter, ånder og genstande igennem formelagtige sange. Planter og dyr er beskyttet af ånder som sanktionerer mennesker der ikke respekterer dem. Kvindernes forhold til deres køkkenplanter er som til børn, og kvinder skal passe dem, lige som også planternes ånd gør. Mændenes forhold til vilde dyr er derimod som til deres svogre, altså ikke blodsbeslægtede som børn, men relaterede igennem ægteskabsudveksling - og årsag til evige rivaliseringer og ofte voldelige konflikter.

Et moderne menneske vil typisk se det som en tilfældighed at nogen er så uheldig at blive bidt af en klapperslange; man ved på forhånd at der ingen forbindelse er imellem umoralsk jagt på aber og slangebid. Moderne mennesker forventer ikke moralske sammenhænge i forhold imellem dyr og mennesker, for moral, herunder straf, er noget specifikt menneskeligt. Moral er irrelevant, for dyr og planter er ikke personer - og køkkenredskaber er det da slet ikke. For Achuar-mennesker derimod er mennesker, dyr, planter, redskaber og ånder alle i samme grad levende væsener og personer med mentale evner og moralske principper. Deres levevis er ikke præcis de samme. Fx har nogle af dem de samme ægteskabsregler som mennesker, såsom uldaber, tukaner, maniok, jordnødder og en klasse af flodånder, mens andre lever isoleret uden familie, såsom jaguarer og anakondaer og en anden type ånder (Descola 2013, 7).

I Achuar-sammenhæng vil det være meningsløst at skelne imellem kultur og natur. Dyr, planter og redskaber har ikke kun lige så meget kultur som mennesker - de har den samme slags kultur. Hvor der ikke er nogen principiel forskel imellem mennesker på den ene side og dyr, planter, redskaber og ånder på den anden side, vil det ikke give mening at tale om en 'natur'. Interessant nok vil det så også være meningsløst at skelne som et civiliseret rum (for mennesker) og et vildnis (for ikke-menneskelige væsener) (Descola 2013, 33-56). Der er intet 'vildnis', forstået som rum der er principielt anderledes end det menneskelige rum, når der ikke findes 'vilde dyr', men kun levevæsener der ser anderledes ud, men som ellers er lige så menneskelige som mennesker. ${ }^{18}$ Et møde med en anakonda eller en tapir er ikke et møde med noget 'fremmed',

16 Det gælder ikke mindst Achuar og andre Jivaro-folk, "who spent a great deal of their time trying to kill each other" (Descola 2010, 209).

17 Udførlig beskrivelse af opfattelsen af planter hos Achuar: Descola 1998, Kap. 6: “Garden Magic".

18 Denne dekonstruktion af forestillingen om den vilde natur kan påfaldende nok også begrundes ud fra en nutidig, naturalistisk, virkelighedsforståelse. Fx vil det være problematisk at forstå forekomsten af træer i Amazon-områdets enorme regnskov hvis udgangspunktet er en for strikt modsætning imellem kultur og natur. Menneskers årtusindlange beboelse og indflydelse på plantevæksten er blandt de faktorer der har gjort at den er blevet til hvad den er. Regnskoven er altså ikke simpelthen et 'vildnis' eller en uberørt natur, men resultatet af en 
men med noget velkendt - livsformer der essentielt er lige som en selv. Skellet imellem kultur og natur, civilisation og vildnis opløses hvis alle (relevante) dyr, planter, ånder og genstande i skoven, på steppen, i bjergene er personer, lige som mennesker. Ganske vist kan man ikke direkte tale med dem. Men det kan man heller ikke med flertallet af mennesker, der jo taler et sprog man ikke selv forstår.

En virkelighedsforståelse som den der findes blandt Achuar, foreslår Descola at kalde 'animisme'. Begrebet er gammelt. Det blev indført af den engelske antropolog E.B. Tylor i Primitive Culture (1871; kap. IX, “Animism”). Med 'animisme' forstod Tylor en forestilling om at alle levende væsner havde en sjæl (anima), en forestilling som han antog skyldtes oplevelser i drømme og visioner om at kunne bevæge sig uden for ens krop. Animisme i denne forstand skulle være oprindelsen til religion og til filosofi; græsk metafysik var en direkte efterkommer. Opfattelsen var forståelig nok blandt 'primitive' kulturer. Men det var en illusion, og den var nu stort set udryddet og erstattet af nutidig 'materialisme'. Animisme var oprindelig en 'rude science', altså en slags videnskab, om end 'rude'; nu er den enten gået i glemmebogen eller reduceret til 'sentimental nonsense' (Tylor 1871, 425). James George Frazer der nok var elev af Tylor (men som i øvrigt ikke kunne bruge begrebet 'animisme' til ret meget i The Golden Bough), kunne endnu i 1922, fire år efter afslutningen på første verdenskrigs triumf i henseende til industrielt massedrab, afslutte den forkortede folkeudgave af sit store værk med at forsikre om at fremtidig udvikling ikke kun materielt, men også moralsk og intellektuelt, afhang af videnskaben. ${ }^{19} 150$ år efter Tylor, og med det sene 20. århundredes erfaring af den pris andre arter har måttet betale for den triumferende oplysning og scientisme, kan Tylor og Frazers anti-animistiske position dårligt ses som andet end som en naiv, vestlig-'evolutionistisk' arrogance. Begrebet animisme blev derfor marginaliseret i religionsvidenskaben. Men i stedet for at danne et nyt begreb vil Descola revitalisere det forældede begreb med et delvis nyt indhold. Hovedvægten ligger hos ham ikke, som hos Tylor, på overbevisningen om eksistensen af sjæle og ånder (skønt disse i høj grad er med til at befolke animistiske universer), men på forståelsen af ikke-menneskelige væsener generelt og her særligt dyr og planter - selv om hverken ånder, køkkenredskaber, geologiske eller meteorologiske fænomener nødvendigvis er udelukkede.

Virkelighedsforståelser af samme type som Achuars er udbredt blandt små grupper af mennesker, der lever af jagt og indsamling, navnlig, men ikke kun, i Syd- og Nordamerika og i det østlige Sibirien. Men basale animistiske forestillinger og dertil hørende normer kan genfindes i andre typer samfund, bl.a. som motiver i eventyrlignende fortællinger. Der kan formentlig anføres et utal af eksempler, og mange af disse kan nok hentes fra ældre folkloristik og 'folkemindeforskning', hvis man ville foretage en systematisk sammenligning. Pladsen her tillader kun to eksempler.

symbiose imellem mennesker og mange arter af planter og dyr. Balée 2013, taler således om 'cultural forests'; jf. Descola, 2013, 41.

19 "It is probably not too much to say that the hope of progress - moral and intellectual as well as material - in the future is bound up with the fortunes of science, and that every obstacle placed in the way of scientific discovery is a wrong to humanity" (Frazer 1922, 932). 
For det første: Ovids store heksameterdigt, Forvandlinger (Metamorphoses), genfortæller store dele af en græsk-romersk og mediterran mytologi, hvor fortællingerne har det tilfælles, at noget bliver til noget andet via 'metamorfoser'. Her er der ofte tale om at dyr og planter er beholdere for mennesker. Der fortælles om hvordan mennesker bliver dyr, som fx Lycaon, den onde konge der udfordrer Jupiter ved at servere et kannibalsk måltid og som straf bliver forvandlet til en ulv, eller den uskyldige Callisto, der voldtages af Jupiter, af Juno forvandles til en bjørn, og til sidst bliver til stjernebilledet Store Bjørn. Og der fortælles om mennesker der bliver til planter, som det fattige ældre ægtepar, Philemon og Baucis, der som belønning for deres gæstfri måltid bliver forvandlet til to træer, og om halvguden Adonis' mor der først blev forvandlet til et myrratræ som så, som træ, fødte Adonis. I alle disse tilfælde er kroppen et hylster som ikke forhindrer at væsenerne indeni er mennesker eller menneskelige væsener, som nymfen der boede i et træ, men døde da den overmodige kong Erysichthon begik katastrofal hybris ved at fælde hendes træ. ${ }^{20}$

For det andet: Motivet at gendanne et dyr ud fra dets knogler. Det er almindeligt kendt i fortællingen om Thors gedebukke (Gylfaginning, kap. 43), der kan slagtes, koges og spises og dagen efter gendannes, hvis knoglerne lægges på deres skind og Mjølner svinges over dem. I kristen kontekst bruges det om den store franske helgen Germanus fra Auxerre (fra 400-tallet) som kold og sulten blev modtaget af en fattig hyrde, som slagtede og serverede sin eneste kalv; efter måltidet lagde Germanus knoglerne under huden, og på hans bøn lod Gud kalven genopstå. ${ }^{21}$ Denne narrative episode gengiver en vidt udbredt praksis blandt nord- og sydamerikanske jægere med at tabuisere en del af det nedlagte byttedyr, typisk netop knoglerne, og skaffe sig af med dem, så dyret kan gendannes. At undlade dette er en fornærmelse imod dyrene eller dyrenes ikke-menneskelige herre der så kan svare igen ved for fremtiden at holde sine dyr borte fra de respektløse mennesker (Descola 2013, 15). Givetvis er talrige velkendte forestillinger funderet $\mathrm{i}$ det animistiske princip om en menneskelig person inden i en materiel beholder: personer der er forheksede så de er spærret inde i en fremmed krop (Skønheden og udyret), eller personer som kan iføre sig en krop for at kunne bevæge sig hurtigt igennem rummet (ørne- og falkeham). Dæmoner i NT er menneskelignende væsener - i hvert fald hvad angår deres mentale kapacitet til at tale, huske og ræsonnere. Når de besætter mennesker, er det for at bruge menneskekroppe som deres materielle hylster. Hvis de fordrives, flakker de om, indtil de finder en ny krop (eller den gamle krop) at trænge ind i (således Matt 12,43-45). Det virker altså som om dæmoner her er personer der savner en krop - som et dyrs ånd der ikke kan reinkarnere sig fordi dets knogler ikke er behandlet korrekt. Man kan overveje om ikke spøgelser, der typisk flakker rundt fordi de ikke er begravet ordentligt, har graven eller jorden som deres materielle 'beholder', men er fordømt til hvileløshed indtil et levende menneske forbarmer sig over dem og ved at begrave dem giver dem den hvile de længes efter. Dette

20 Ovids forvandlinger (1989): Lycaon: 1,199-250 (s. 13-15); Callisto: 2,55-507 (s. 55-60); Philemon og Baucis: 8,611-724 (s. 263-268); Myrra og Adonis: 10,488-514 (s. 328-330); Erysichthon: 8,739776 (s. 268-270) - blandt utallige eksempler. Dansk oversættelse: Ovid 1989.

21 Thor: Gylfaginning 43; Germanus: Legenda Aurea, kap. 106.

74 Hans J. Lundager Jensen 
ville være en nærliggende, transkulturel, forklaring på det nødvendige og barmhjertige ved at give døde en ordentlig begravelse: Da deres kroppe går i opløsning, bør de få et stabilt opholdssted. 22

Animistiske principper kan formentlig følges ned igennem religionshistorien igennem mange transformationer. En af disse kan være slagtofferet i den form der kendes fra bl.a. antik græsk og gammeltestamentlig religion, og som er typisk, ikke for animisme i den rene og 'tribale' udgave, men for arkaisk religion. Her tabuiseres en del af dyrekroppen (græsk: lårbensknogler; GT: indvoldsfedtet) som først brændes og dermed gives til en guddom, før deltagerne i kulten kan spise resten af dyret. Proceduren artikulerer både en belæring om nødvendigheden af begærsudskydelse eller impulskontrol og en forventning om også i fremtiden at kunne modtage og spise tilsvarende dyr. Denne type offer kan nok siges at forbinde tribal og arkaisk religion. Det arkaiske (med få, store og himmelske guddomme som har skabt verden og stadfæstet de basale sociale leveregler), vil i så fald repræsentere en post-tribal og post-animistisk forestillingsverden. Men forholdet imellem mennesker og et ikke-menneskeligt domæne der leverer dyr til menneskenes konsum, udtrykker en animistisk grundstruktur.

Allerede i amerikansk animisme er der dog ansatser til den arkaiske konstellation der artikuleres i offeret. For det ikke-menneskelige domæne synes at kunne have i hvert fald to former. Dyrene kan agere som et kollektiv i forhold til menneskene; hvis én af deres fæller fratages muligheden for at regenereres, holder de sig alle på afstand. Således fx i en canadisk myte om en jæger der lærer reglerne for hjortejagt igennem et ægteskab med en hjortekvinde. ${ }^{23}$ Men dyrene kan også tilhøre en 'vildtets herre' - en ikke-menneskelig person der bestyrer og dirigerer en bestemt art eller alle dyr - og det er denne herre, menneskene skal forholde sig til i deres håb om fortsat at kunne få adgang til jagtbytte. ${ }^{24}$ To modeller altså: en 'republikansk' (kan man måske kalde det) og horisontal, hvor dyrene og menneskene er relativt ligestillede (byttedyrene behøver ganske vist ikke menneskene, men det gør rovdyr til gengæld), og en 'monarkisk', hvor det vertikale forhold imellem dyrene og deres herre peger frem imod arkaisk religion hvor også menneskene underlægges 'herrer': menneskelige og guddommelige.

Forholdet imellem ontologier - her animismen og den ontologi der ligger under arkaisk religion, analogismen, som skal beskrives nedenfor - skal givetvis ikke tages

22 Således i den gammeltestamentlige apokryfe Tobits Bog, hvor Tobit fortjenstfuld engagerer sig i at sikre døde en ordentlig begravelse. Det er velkendt at denne antikke fortælling gør brug af det basiseventyr om 'den taknemmelige døde' ('the grateful dead'), som H.C. Andersen videreskrev i eventyret om 'Rejsekammeraten' (Otzen 2002, 8-11).

23 Denne myte, hvis grundform er vidt udbredt, kommenteres i Fibiger \& Lundager Jensen, eds., Andre verdener, kap. 2.2.1.

24 Forestillingen om 'Dyrenes herre' er i øvrigt Descolas (2013, 384; 1998, bl.a. s. 126) forklaring på hvorfor der ikke forekom domesticering af dyr i Nord-og Sydamerika (bortset fra hunde), før den europæiske invasion. Alle dyr var allerede 'domesticerede', ikke af mennesker, men af deres ikke-menneskelige beskyttere. Descolas indvending støtter sig på at mennesker i Amazon-kulturer typisk er omgivet af tamme dyr (fra papegøjer til tapirer), men at disse betragtes som medlemmer af husstanden og kan derfor ikke spises. 
alt for absolut. Som i alle tilfælde hvor det drejer sig om nyttige kategoriseringer, rejser spørgsmålet sig altid om mellempositioner og fænomener som har ligheder med mere end en kategori. Det kan også gælde den animistiske forestilling om vildtets sted hvorfra dyrene kommer og hvortil de vender tilbage. Dette sted kan forestilles som en bolig uden for det kendte menneskelige domæne, fx som en underjordisk hal med en normalt usynlig indgang, som kun mytiske helte og nutidige shamaner har adgang til. Ofte har i hvert fald amerindiske myter en beslægtet forestilling med omvendt fortegn: I begyndelsen var alle byttedyr (eller kulturplanter) samlet et sted, enten som et blot faktum eller fordi en begærlig ejer ikke ville frigive dem til andre. Ved en samlet aktion af urtidsvæsener, formentlig mennesker med træk af de dyr som de skal blive til, lykkes det at få frigivet de indespærrede væsener, så de kan fordeles ud over verden og mange kan få glæde af dem. ${ }^{25}$ Her synes aftegnet en struktur der dels har sin egen, særlige udformning i australsk totemisme, dels videreføres i arkaiske templer: et centralt sted hvor rigdommene er samlet og hvorfra de kan strømme ud i det omgivende rum. I arkaisk religion kan dette sted, i form af et prestigefyldt tempel, nok siges at være en 'axis mundi'. Men en kosmologisk kodning skal nok ikke tages for givet eller anses som specielt vigtigt. Mere betydningsfuld er grundstrukturen: et sted og dets omverden, koncentration af rigdomme og fordelingen af dem, i en mytisk urtid som i amerindisk-animistiske myter, eller i det daglige livs nutid, som i arkaiske templer.

Afrundende bør kontrasten imellem naturalisme og animisme atter fremhæves. Begge ontologier er grundlæggende dualistiske, for de modstiller begge en materiel krop og et menneskelignende indre. Men de er også symmetrisk omvendte. For naturalismen er mennesker afgørende forskellige fra dyr ved at have et indre væsen, mens dyr er ren krop. For animismen er mennesker ikke væsentligt forskellige fra dyr, for dyr er mennesker inde i en anden krop (som de kan aflægge sig). Naturalisten kan behandle dyr som ting; dette er omvendt den grundlæggende moralske fejl ifølge animismen - en fejl der sanktioneres kontant. Det er kun logisk at forestillingen om tilblivelsen af mennesker og dyr derfor også er symmetrisk omvendt. For naturalismen er menneskene udviklet fra dyr; engang var der kun dyr, men igennem en evolution har der dannet sig et indre væsen der nu huses i menneskelige kroppe. For animismen er det omvendt: Oprindeligt, i tidernes mytiske morgen (der kan ligge bare nogle få generationer tilbage: Descola 2011, 88f), fandtes der kun mennesker; men nogle af disse besad visse egenskaber der forberedte dem til at forvandle og herefter fremtræde som dyr og planter. For animismen kommer dyr og planter altså fra menneskene, og de har bevaret deres essentielle, menneskelige egenskaber. Dette forklarer også et gennemgående træk i amerindiske myter: at mennesker har seksuelle forbindelser og ægteskaber med dyr, og at dyr kan optræde som nære slægtninge til mennesker (som fx i en nordamerikansk version af den berømte fugleredeplyndrermyte, hvor et ældre edderkoppepar er heltens bedstefar og bedstemor; Teit 1898, 24).

25 Byttedyr: fx Navajo: Luckert 1975: 135; kulturplanter, fx Amazon-stammers myter om at majs oprindeligt skulle komme fra et mirakuløst og overdådigt træ, der blev fældet - derfor de nuværende begrænsede mængder af majs (Lévi-Strauss 1964, 173-176). 
Claude Lévi-Strauss, der beskrev og analyserede et stort antal amerindiske myter, forstod den mytiske tid som en tilstand hvor der ikke var forskel på dyr og mennesker (Lévi-Strauss 1988, 192). Det kan forklare hvorfor den fortælling, han udvalgte sig som det faste forankringspunkt for sin storslåede gennemtrævling af over tusind myter fra tribale samfund i Syd- og Nordamerika, kunne handle om en dreng der blev adopteret af en venlig jaguar og blev plaget af dennes mindre venlige hustru. Han forstod også myterne som fortællinger om hvordan mennesker blev til mennesker og dyr blev til dyr. Eller sagt på en anden måde: Disse myters fælles anliggende er at fortælle (og dvs. tænke) oprindelsen til hvordan kulturen, menneskenes verden, opstod af naturen, dyrenes verden. Men det er faktisk ikke en præcis forståelse af animismen, ifølge Descola. Urtidens væsener var alle mennesker, og nogle af dem bliver til dyr. Det kunne altså være fristende at forstå myternes forløb (imod Lévi-Strauss) som fortællinger om hvordan naturen opstod af kulturen. Men det ville heller ikke være præcist. Skellet imellem natur og kultur giver ingen mening i en animistisk ontologi, for dyr og planter har lige så meget 'kultur' som mennesker. (I et tillæg til denne artikel redegør jeg mere udførligt for problemet med Lévi-Strauss' miskendelse af animismen og giver et bud på en begrundelse for denne miskendelse).

\section{Totemisme}

Mens senere religionshistoriske faser forekommer at være baseret på én bestemt ontologi, som det vil fremgå nedenfor, kan man ikke identificere tribal religion med animisme. For hos oprindelige jæger-samler-samfund i Australien dominerer en særlig ontologi der ikke er animistisk. Lige som 'animisme' er 'totemisme' en term hentet fra den antropologiske forskningstradition der hos Descola får en særlig definition. Denne australske ontologi er i sig selv tankevækkende. Man bør ikke udelukke at der kan være punktuelle forekomster af bestemte sider ved den i senere udviklede religionsformer og altså inden for rammerne af andre ontologier. Men i sin 'rene' form er den vistnok unik. ${ }^{26}$

Med 'totemisme' mener Descola en forståelse af at bestemte grupper af mennesker - fx en 'klan' eller en halvdel ('moiety') af en større gruppe - hører essentielt sammen med forskellige arter af dyr og planter og evt. forskellige andet som fx kropsdele, redskaber og atmosfæriske fænomener. Sammenhængen fremgår af de betegnelser som den enkelte klan giver sig selv; populært sagt: De kalder sig kænguruer eller kakaduer. I den antropologiske tradition blev sammenhængen gerne forstået sådan at en 'kænguruklan' skulle mene at skulle nedstamme fra kænguruer og derfor have bestemte

26 Descolas kapitel om totemisme er i 2013, 144-171. De etnografiske informationer er de klassiske beskrivelser af bl.a. Spencer \& Gillen (The Native Tribes of Central Australia, 1899; The Arunta: A Study of a Stone-Age People, 1927) som Descola betegner som 'fremragende' (p. 145), og Adolphus Elkin ("Studies in Australian Totemism: The Nature of Australian Totemism", Oceania 4 (2), 1933, 113-131) (også informativt er Bellah 2011, 146-159). En vigtig inspiration for Descolas alternativ til Lévi-Strauss' forståelse af totemisme er Luc Racine, "Du modèle analogique dans l'analyse des représentations magico-religieuses", L'homme 109, 5-25; jf. Descola \& Charbonnier 2014, 205. 
egenskaber til fælles med kænguruer. Derfor kunne et menneske inden for denne virkelighedsforståelse hævde at være en kænguru - for naturalister en bizar påstand. Totemismen kunne altså fremstå som indbegrebet af ikke-vestlig irrationalitet. Heroverfor ville Claude Lévi-Strauss i et indflydelsesrigt lille studie, Le totémisme aujourd'hui (1962) betragte totemistiske betegnelser som rene emblemer der brugtes for at kunne skelne imellem klaner. Dermed blev 'naturen' - de naturligt forekommende arter altså blive brugt som spejl for 'kulturen'. Som kænguruer i den materielle verden forholder sig til fx kakaduer, således skulle klan A i den sociale verden forholde sig til klan B. Og 'at være kænguru' ville altså egentlig betyde 'at være forskellig fra klan B, lige som kænguruer er forskellige fra kakaduer'. Pointen var at det tilsyneladende irrationelle udsagn: 'Jeg er en kænguru', kunne oversættes med det rationelle udsagn: 'Jeg tilhører en gruppe der har emblemet kænguru, så vi kan adskille os fra en anden gruppe som har emblemet kakadue'.

Descola $(2013,155-162)$ indvender herimod at det vist sig at de indfødte, australske betegnelser for klaner faktisk ikke er betegnelser for dyr og planter, men ord for abstrakte kvaliteter. ${ }^{27}$ Fx er to halvdele af et samfund hhv. 'langnæbede kakaduer' og 'krager'. Men de australske ord for de to dyrearter betyder i virkeligheden hhv. 'en der skaffer' og 'en der holder vagt'. 'Kakadue' og 'krage ' skal i dette tilfælde altså forstås som 'skafferen' og 'den vagtsomme'. Og det er disse kvaliteter som de to dyrearter har til fælles med de to menneskegrupper. Kakadue-mennesker 'er' altså ikke kakaduer, men 'skaffere' - en essentiel egenskab de deler med kakaduer - og i øvrigt med ørne, pelikaner, slanger, myg og hvaler. I sig selv er en sådan tankegang nok ikke så underlig. Selv overbeviste naturalister kender sikkert tilfælde hvor mennesker (og undertiden menneskelige kollektiver) passende kan klassificeres som fx ræve, svin eller svesker.

Ifølge australsk totemisme nedstammer menneskegrupper ikke fra dyr eller planter, men fra urtidsvæsener (i 'drømmetiden') som vandrede hen over jordoverfladen og til sidst forsvandt ned i jorden - men ikke før de havde videregivet deres essentielle egenskaber (som fx vagtsomhed) til bestemte grupper af mennesker, dyr, planter osv. Disse steder i landskabet hvor urtidsvæsenerne forsvandt, er nu reservoirer for fortsat formidling af de bestemte egenskaber. En klan vil med mellemrum samles et sådant sted og gennemføre et ritual der revitaliserer de særlige egenskaber i kraft af hvilke både den selv og andre arter lever. Drømmetidsvæsenerne var ikke specielt kakaduer eller ørne eller mennesker. Nogle af dem var hybrider af mennesker og andre væsener. Det afgørende er at de besad en livsessens som de videregav til fx kakaduer og ørne og en bestemt klan af mennesker. Drømmetidsvæsenerne er forsvundet nu, forsvundet ned i jorden eller materialiseret som klippeformationer eller vandhuller; men de er fortsat levende og virksomme. De bør derfor ikke forstås hverken som fortidige helte eller som forfædre. De er ikke mennesker som nutidens mennesker, og de tilhører nutiden lige som meget som fortiden.

27 Descola henviser til lingvisten Carl Georg Brandenstein (Names and Substances of the Australian Subsection System, 1982). 
De særlige klanegenskaber er på samme tid kropslige og indre, dvs. moralske og psykologiske; de udgør en kontinuitet, én identitet. Her kan der ikke som i naturalisme og animisme skelnes imellem det indre og det ydre i den enkelte organisme eller person; 'vagtsomhed' gennemsyrer den vagtsomme/krage-personen og bestemmer både krop og mentale egenskaber. I forhold til animismens og naturalismens dualistiske skelnen imellem indre vs. ydre og identitet vs. forskel bør totemismen altså forstås som en monisme hvor der er identitet imellem ind og ydre. Vagtsomme væsener er vagtsomme hele vejen igennem; de har ikke en vagtsomheds-størrelse (fx en vagtsom ånd) 'inden i' sig. Derimod er der klare forskelle imellem væsener inden for en totemgruppe (krager, krage-mennesker osv.) og væsener i en anden gruppe (kakaduer, kakaduemennesker osv.). De er og har forskellige væsener, for de nedstammer fra forskellige urtidsvæsener der har leveret og fortsat leverer de livskræfter som gør at de lever og lever på deres særlige måder.

Imidlertid indebærer et menneskes tilhørsforhold til en gruppe væsener med de samme egenskaber (som fx kakadue-menneskene) dog ikke at de i alle henseende er som de dyr der også tilhører gruppen. I modsætning til dyrene i deres gruppe der kun kan parre sig med hinanden, skal mennesker vælge deres partnere fra en anden klan end den de selv tilhører. For mennesker tilhører gerne forskellige slags kollektiver eller 'klaner' samtidig, bestemt af $\mathrm{fx}$ køn, generation eller undfangelsessted. Og menneskene i en given klan vil typisk indtage en nøglestilling blandt de andre arter af planter og dyr, for det er menneskene som kan opretholde og fremme den særlige essens eller livskraft som holder hele klanen, både den menneskelige del og de associerede dyrearter, i live. Dette sker ved rituelle aktiviteter ved bestemte hellige steder i landskabet. Og denne aktivitet er ikke kun til glæde for klanen selv, men også for andre klaner der måtte jage eller indsamle eksemplarer af disse arter. Hvor Lévi-Strauss ville se totemismen som en rationel organisering af samfund i grupper, ser Descola den derfor som en regulær religion (ibid., 153; jf. også Désveaux 1992). For selv om en given klan har en essentiel livskraft til fælles med en gruppe af dyre- og plantearter, er det den menneskelige del af klanen der har den særlige opgave at formidle drømmetidsvæsenets og dets steds livsessenser ud til de andre arter i deres gruppe. Og det sker ved de genkommende fester med ritualer, danse og sange. Menneskeklanen skaber ikke deres eget og deres gruppes liv: men den sørger for at det fortsat realiseres, holdes i live.

\section{Analogisme}

At Descola kan regne med fire ontologier, skyldes i første omgang et rent deduktivt ræsonnement. Han går ud fra to elementære modsætninger, som antages at være givet med den basale humane kognition: For det første modsætningen imellem det ydre og det indre af en krop og for det andet modsætningen imellem identitet og forskel (alle sprog har betegnelser for et 'jeg' og et ' $\mathrm{du}^{\prime}$ '; Descola 2013, 117). Ifølge naturalismen vil der som sagt være identitet i det ydre (kroppenes beskaffenhed) forskel i det indre (mennesket har et indre, i modsætning til alle andre). Ud fra denne kombination kan man antage at der findes en anden virkelighedsforståelse hvor identitet og forskel er 
omvendt fordelt: Der vil så være forskel i det ydre og identitet i det indre. Denne tænkte mulighed kan også findes i den virkelige verden: Det er animismen. Men nu har totemismen vist sig som en tredje mulighed: Der er identitet både i det indre og i det ydre. I så fald kan man gætte at der også gives en fjerde mulighed, som er omvendt af totemismen, lige som animismen er omvendt af naturalismen - dvs. at der er forskel både i kroppens indre og dens ydre. I en sådan ontologi vil det dominerende indtryk være netop forskellene: Mennesker, dyr, planter og alt andet (relevant) vil her frem for alt være forskellige. Også på dén betingelse kan der i øvrigt godt tænkes også en beholder-forestilling, altså at et væsens krop inde i sig rummer en sjæl eller noget tilsvarende. Men i dette tilfælde vil sjælen være lige så forskellig fra andre sjæle som den krop den er indeni, er forskellige fra de andre kroppe. Denne fjerde, i første omgang rent teoretiske mulighed, kalder Descola for 'analogisme'.

De to modsætningsrelationer: indre/ydre og identitet/forskel kan altså kombineres på fire måder, svarende til fire ontologier:

\begin{tabular}{|l|l|l|l|}
\hline animisme & $\begin{array}{l}\text { indre: ens } \\
\text { ydre: forskelligt }\end{array}$ & $\begin{array}{l}\text { indre: ens } \\
\text { ydre: ens }\end{array}$ & totemisme \\
\hline naturalisme & $\begin{array}{l}\text { indre: forskelligt } \\
\text { ydre: ens }\end{array}$ & $\begin{array}{l}\text { indre: forskelligt } \\
\text { ydre: forskelligt }\end{array}$ & analogisme \\
\hline
\end{tabular}

At noget er tænkeligt, er ikke det samme som at det faktisk findes. Men en deduktion kan give anledning til at undersøge. Findes der altså en i virkelighedsforståelse som ikke er naturalistisk, men som heller ikke er hverken animistisk eller totemistisk? Og hvis der gør, forekommer den så som en etnografisk kuriositet, eller er den relevant også for religionsvidenskaben i bred forstand? Svaret er bekræftende: Den findes, og den er tilmed ekstremt relevant. For det er en ontologi der er fælles for de tidlige højkulturer: de nærorientalske som i Mesopotamien og Egypten, i Asien som i Indien og Kina, og tilmed i de amerindiske højkulturer (Maya, Azteker, Inkaer, og deres forløberkulturer), og som også har domineret europæisk tænkning til og med renæssancen. Den ontologi som gik umiddelbart forud for naturalismen og som denne nu har marginaliseret, var ikke primært animisme eller totemisme, men analogismen.

Betegnelsen analogisme er lånt fra den franske sinologs Marcel Granets karakteristik af klassisk kinesisk tænkning (der fordeler alting ud fra en grundlæggende dualitet, principperne yin og yang). ${ }^{28}$ Et andet eksempel (som Descola ikke nævner) kunne være den indoeuropæiske trefunktions-tænkning, der potentielt fordeler alt på én af tre kategorier: suverænitet, kamp og frugtbarhed, som Georges Dumézil viste. Dette skema kan fordele guddomme, konger, samfundsklasser, synder, heltegerninger, ægteskabsformer og andet. I et sådant system består der forbindelser på kryds og tværs imellem potentielt alt muligt: en guddom betegner en samfundsklasse og omvendt. De 
enkelte dele er dermed analoge i betydningen tegn for eller henvisninger til noget andet. Hvad der kan henvise til hvad, bestemmes så i den konkrete udgave, der kan være fx dualt som det kinesiske, triadisk som det indoeuropæiske eller fireleddet som i mange amerindiske højkulturer.

Begrebet om en analogistisk ontologi vil være særlig betydningsfuldt for religionsvidenskaben. Forskningshistorisk har den særlig ladet sig inspirere af etnografien og antropologien. Etnografiske hovedværker og mestertænkere har haft samme status i religionsvidenskaben, fra E.B. Tylor og til Clifford Geertz og Roy A. Rappaport. Religionsvidenskaben har været i modtagerens rolle i dette forhold; man kan ikke tænke sig nutidens religionsvidenskab uden denne overførelse af informationer, teorier og begreber. Man træffer stadig en forestilling om at tribal religion (hhv. 'naturfolks', 'skriftløse folks' religion) må være en uundværlig del af en religionsvidenskabelig uddannelses curriculum, og at en tilsvarende forskningsmæssig kompetence må indgå i en religionsvidenskabelig universitetsafdelings bemanding. Men en omkostning ved religionsvidenskabens fascination af antropologien har været at religionshistoriens store felter: de tidlige højkulturers religioner og de postaksiale verdensreligioner, hyppigt er blevet overset, overladt til filologers og historikeres ekspertise.

I en analogistisk ontologi vil der som sagt ikke gælde en dualistisk forståelse af kroppen som i naturalisme og animisme. Så langt ligner analogismen totemismen. Men mens totemismen understreger identiteten imellem (en gruppe) mennesker og (en gruppe) dyr og planter, understreger analogismen forskellene; i Gen 1 skaber Gud planterne og dyrene 'efter deres arter'. Her vil mennesker være forskellige fra dyr og planter, men disse vil selv være indbyrdes forskellige. Hvor animismen særligt fokuserer på en umiddelbar relation imellem et menneske og et andet væsen (fx jægeren og byttedyret, den havedyrkende kvinde og hendes planter), og totemismen fokuserer på en gruppe væseners relation til et bestemt sted, er analogismen indrettet på at tænke store mængder og antal - af dyr og planter, af mennesker, at guder og ånder, af himmelske fænomener. En given mængde forstås så som en helhed af individuelle størrelser, der alle har hver deres identitet. Men da mængden er stor, vil de relative forskelle imellem de individuelle størrelser være relativt lille.

Man kan med animismen let forestille sig en stor og klar forskel imellem fx et menneske og en hjort. Men i en analogistisk mængde vil det være umuligt at se markante forskelle imellem de enkelte hjorte, stenbukke, gazeller, klippegrævlinger, harer, kvæg, heste, æsler, får, geder osv. Forskellene imellem de enkelte væsener vil så justeres ved at væsener rubriceres i kategorier: alle hjorte, alle stenbukke osv. Og de kan så tænkes forbundet på mange måder - fx at de tilhører en fælles overkategori som fx 'tilladt til spise og tilladte som offer' (kvæg, får, geder), 'tilladt til spise, men ikke til offer' (fx hjorte, gazeller), 'hverken tilladte til spise eller til offer' (fx klippegrævlinger, æsler), kostbare vs. mindre kostbare (fx kvæg vs. geder). Ud fra nogle enkle modsætninger som 'tilladt vs. forbudt at spise' og 'tilladt vs. forbudt at bringe som offer') kan dyrene kategoriseres i komplekse, men sammenhængende systemer. 
Mit eksempel her på en analogistisk ordning er hentet fra de gammeltestamentlige spise- og offerregler i Leviticus. Den kan overfladisk ligne en nutidig, zoologisk klassifikation. Historisk er der givetvis også en kontinuitet, for videnskabelige klassifikationer forudsætter evnen til at skabe klassifikationer, og denne evne er udviklet inden for analogistiske rammer. Men i sig selv er analogistiske klassifikationer selvberoende, med deres egne principper. I det gammeltestamentlige tilfælde kan der fx udledes en klassifikation af mennesker, som anbringer dem i samme klasse som æsler. Der gælder den generelle regel (ifølge Ex 13,11-13) at 'alt det første, der kommer ud af moderlivet, skal man overgive til Jahve'. Førstefødte handyr af kvæg, får og geder, de udbredte husdyr, skal altså overbringes til templet. Æsler var også udbredte husdyr; men de måtte hverken spises eller ofres og kunne derfor ikke bringes som ydelse til templet. Derfor skulle de erstattes med et får (et lam) eller en ged (et kid); alternativt skulle man brække halsen på det. Førstefødte menneskesønner skulle også frikøbes (der var dog ingen regel om at de alternativt skulle have samme skæbne som æsler). Mennesker klassificeres altså her sammen med æsler, i modsætning til kvæg, får og geder, for heller ikke mennesker må spises. Dette er tydeligvis ikke en præ-linnéesk klassifikation. At mennesker skulle være 'beslægtede' med netop æsler, kan virke overraskende. Men Linnées klassifikation af mennesker sammen med aber som primater i hans Systema naturae (12. og sidste udg. 1766-68) skandaliserede også mange mennesker i hans samtid. ${ }^{29} \mathrm{Og}$ begge klassifikationer giver mening; de forbinder umiddelbart adskilte og enkeltstående størrelser i en mere omfattende ordning, hvor de enkelte dele indbyrdes henviser til hinanden. I dette gammeltestamentlige eksempel er det også tydeligt hvordan analogismen adskiller sig fra naturalismen: Der er ikke plads til en kategori 'natur'. Der er mennesker og andre dyr; men der er ikke en overordnet sondring imellem to væsensforskellige domæner med dyrene på naturens og menneskene på kulturens (hhv. på bevidsthedens, åndens eller lignende) side.

Mit eksempel her kan udfoldes videre så der også vil vise sig et hierarkisk princip; for Jahve er en del af helheden, både som den aktør der sætter reglerne og som modtager af offergaverne. Men dette kan vises meget tydeligere med et andet og mere berømt eksempel, nu fra den religionshistoriske kanon, der desuden kan illustrere andre og nok så væsentlige træk ved analogismen: Purusha-hymnen fra Rigveda (10.90). Purusha, det første menneske, der også er det første offer, inkarnerer enorm mangfoldighed: han har tusind hoveder, øjne og fødder. Han udgør totaliteten af alt hvad der har været og vil være. Han er enorm og så stor at den del af ham der er på jorden, kun udgør en fjerdedel, mens resten af ham er i himlen. Han er indbegrebet af oprindelse

29 Linnée selv skal nok ikke forstås som en konsekvent naturalist; imod 'teologerne' der betragtede dyr som automater i modsætning til mennesker, der havde en sjæl, ville han (analogistisk!) foretrække at også dyr havde en sjæl og at forskellen skulle være grader af værdighed (ifølge eng. Wikipedia: "Carl Linneus" (set 2021-04-14), med reference). - Idéhistorisk er det forståligt at Linnée forbandt naturalisme med netop teologi. For nok går naturalismens rødder tilbage til mødet imellem oldgræsk og bibelsk tænkning (Descola 2013, 66); men dens umiddelbare idéhistoriske forudsætninger er teologiske udviklinger i overgangen fra høj- til senmiddelalder (herunder 1200-1300-tallets franciskanske teologi), som hævdet af bl.a. Dupré 1993. 
og sammenhæng for af ham fødes Viraj (et andet urtidsvæsen) der så paradoksalt føder Purusha. De tre hoveddele af det offer han udgør: olien, træet og selve offergaven, er også tre årstider: forår, sommer og efterår. Alle levende væsener fødes af ham: vilde dyr, fugle og husdyr, og også hymner og rituelle formularer. En særlig vigtig funktion i hymnen udgøres af Purushas krop. Månen og solen kommer fra hans bevidsthed og fra hans øje; fra hans mund kommer guderne Indra og Agni, fra hans åndedræt guden Vayu; himmelhvælvingen og jorden kommer fra hhv. hans navlestreng og hans fødder. Særlig berømt er at de fire klasser af mennesker kommer fra hans krop: præster, krigere, producenter og tjenere kommer fra hhv. hans hoved, hans arme, hans lår og hans fødder. ${ }^{30}$

Med andre ord: Purusha samler mangfoldighed, totalitet, storhed, sammenhæng, offer, levende væsener, kosmiske størrelser og sociale klasser. Disse fænomener udgør ikke en kaotisk mangfoldighed, men en velordnet helhed fordi de alle kan føres tilbage til Purushas krop. Og helheden er desuden hierarkisk: Som hovedet er mere end arme, der er mere end lår, der er mere end fødder, har præster højere status end krigere etc. Men alle har en plads i den hierarkiske orden; måne, sol og vind er lige uundværlige, lige som præster og tjenere. Denne orden er derfor også funktionel. ${ }^{31}$ Hvad der måtte være af destruktive og kaotiske kræfter (fx dæmoner) ligger uden for den. Heller ikke her vil det være relevant at indføre en skelnen imellem natur og kultur. Interessant nok synes denne hymne ikke at være interesseret i en særlig kategori 'menneske'. Det relevante er forskellene imellem forskellige slags mennesker, og disse forskelle er overskuelige for der er netop fire slags; og de interne forskelle her er af samme art som de interne forskelle imellem guderne og himmellegemerne.

I sin korte kommentar til denne tekst fremhæver Gavin Flood $(1966,48)$ 'kosmologisk homologi' (en betegnelse fra Eliade) som 'a principle of Indian religion', sådan som det navnlig viser sig i identifikationen eller homologien imellem kroppen, universet og offeret. Formentlig er dette princip dog ikke unikt indisk. Det kan være specifikt indisk i sin konkrete udformning, men der er intet specielt indisk i at ville forstå det værende som en omfattende, men hierarkisk velordnet helhed, hvor der er plads til mennesker og dyr, ved siden af guder, himmellegemer og kosmos' forskellige dele. $\mathrm{Og}$ at netop menneskekroppen bruges som en slags fælles-metafor for helheden, er heller ikke specielt indisk. Denne form for korrespondance imellem mikrokosmos og makrokosmos er globalt udbredt, fra aztekere over kinesisk filosofi til europæisk renæssance. ${ }^{32}$

30 En lignende analogi imellem et socialt hierarki og andre hierarkier kendes også fra Platons Staten: Her svarer filosoffer, soldater og producenter til intellekt, temperament og begær, og i øvrigt også til guld, sølv og jern-bronze.

31 Analogisme er også funktionalisme: Descola 2010, 223.

32 Descola 2013, 217f.: og de forekommer endnu i 'nutidens horoskop-vogtere, tilhængere af alternativ medicin og følgere af New Age-sekter'. - Jf. analogisme i europæisk renæssance: Michel Foucault, Les mots et les choses, kap. 1 (1966), er en vigtig inspiration for rekonstruktionen af analogisme som en ontologi; men de forståelsesformer Foucault analyserede, var netop ikke specielt europæiske. 
Analogisme kan udtrykke sig på mange måder. Et givet fænomen (fx en tekst) er analogistisk hvis det rummer (1) et større antal enkeltstørrelser med relativt små interne forskelle, (2) en antagelse eller en påstand om at disse enkeltstørrelser dels udgør en mangfoldighed, (3) at der består en sammenhæng, en orden, imellem dem, således at de i en eller anden forstand spejler eller reflekterer hinanden og dermed kan betegne hinanden, (4) og sådan at de udgør et funktionelt og meningsfuldt hele. Typisk vil den forudsatte orden være hierarkisk så nogle af størrelserne er vigtigere eller har en højere status end andre, samtidig med at de alle indgår i en fælles orden. Dertil kommer et gennemgående æstetisk træk: Den samlede orden er ikke kun funktionel god, den er også æstetisk skøn - for nu at bruge en skelnen der er mere typisk for en naturalistisk end for en analogistisk ontologi. I den sidstnævnte vil funktionalitet og skønhed typisk være det samme - som fx i den bibelske skabelsesberetning hvor Gud så at den skabte verden var 'god'. ${ }^{33}$

Der kan nævnes mange eksempler på udslag af en analogistisk orden: konstellationer ( $\mathrm{f} x$ af guddomme), billeder, statuer, monumentalbyggeri og organisering af tempel- og rum, hymniske lovprisninger af guders eller den skabte verdens mangfoldighed, og meget andet. Det er slående at analogistiske udtryksformer et langt stykke er sammenfaldende træk ved arkaisk religion, som nævnt ovenfor. Relationen imellem ontologier og religionshistoriske faser vil jeg tage op nedenfor.

\section{Relationsformer}

Som supplement til skemaet over ontologier giver Descola i Beyond Nature and Culture også en oversigt over typiske 'relationsformer' (forms of attachement) - dvs. måder på hvordan handlende aktører ser på og interagerer med hinanden (kap. 13, p. 309-335). Den amerikanske humorist Will Rogers "I never met a man I didn't like" og den engelske 1600-tals-filosof Thomas Hobbes 'homo homini lupus est' ('et menneske er en ulv over for et andet menneske') er to eksempler på hvordan relationsformer kan anskues. Her drejer det sig altså ikke om hvad og hvordan størrelser er, men hvordan de forholder sig til hinanden. Man kan måske sige at de forholder sig til ontologierne som ethos ifølge Geertz forholder sig til verdensbillede. Relationsformerne er deducerede på samme måde som de fire ontologier; men Descola regner med seks former, der altså ikke svarer præcist til bestemte ontologier. Også her er der en begrebsafklaring som vil være nyttig for religionsvidenskaben.

Et praktisk udgangspunkt kan være kategorien gave, et begreb som har tiltrukket sig en enorm interesse i krydsfeltet imellem antropologi og filosofi, lige siden Marcel Mauss' korte, interessante (og noget skæve) bog 'Essay om gaven', Essai sur le don, fra 1923-24. Prominente navne som sociologen Pierre Bourdieu, filosoffen Jacques Derrida, antropologen Maurice Godelier, teologen John Milbank og mange andre har vendt og drejet gaven, der er blevet bestemt som den første og universelle udslag af 
socialitet, eller reduceret til 'ikke andet end' falsk bevidsthed om økonomisk udbytning, eller ophøjet til en forestilling uden gang på jorden eller defineret som grundstrukturen i en revitaliseret (post-protestantisk) kristen teologi. ${ }^{34}$ Men denne diskussion truer også med at gøre begrebet gave uklart som deskriptiv term i en beskrivelse af religiøse fænomener. Her kan Descolas greb komme til hjælp. Usofistikeret og håndfast (og imod Mauss) definerer han gave som overførelse af noget værdifuldt uden giverens forventning om en modydelse. I mange jægersamfund ( $f x$ fra området Chaco i det sydligt-centrale Sydamerika), kan nedlagte byttedyr således forstås som en ydelse fra dyret selv eller fra dets ikke-menneskelige ejer. Jægeren kan her nok forventes at handle ansvarligt for ikke at stoppe fremtidig generøsitet; men der forventes ikke en egentlig modydelse over for dyrene eller deres ejere (Descola 2013, 316-318; 352-359).

I andre jægersamfund, herunder Descolas egne værter, Achuar, gælder en omvendt indstilling. Her er alle jægere der jager andre: Mennesker jager og nedlægger dyr og andre mennesker og bliver selv jaget og nedlagt af dyr og mennesker. Maniokplanterne, den vigtigste kilde til kulhydrater, er ganske vist små børn der først passes og siden spises af mennesker; men de er også blodtørstige vampyrer der gerne suger blod fra og dermed dræber menneskespædbørn. Her ser man altså sig selv som rovdyr omgivet af rovdyr af alle slags. Alle tager her til sig uden at føle sig forpligtet til at skulle yde noget til gengæld. Hvor fx Mauss ville se gaven som den enkleste og mest basale relation, kan man i dette og lignende tilfælde se prædation som en lige så elementær relation; mange nutidsmennesker spiser jo også dyr, og alle spiser planter, uden at føle at de skylder dyrene og planterne noget til gengæld. ${ }^{35}$

Både gave og prædation er 'horisontale' og ækvivalente: den tagende og givende er på samme niveau. Dette gælder også en tredje mulighed: at begge parter både giver og tager. I så fald vil den dominerende relation være udveksling. Mennesker modtager dyr og planter fra venlige ikke-menneskelige givere. Men de menneskelige modtagere skylder så også at levere en tilsvarende mængde tilbage. Hos Tukano-folkene (i det nordvestlige Amazon-område; Descola 2013, 345-352) ses mennesker og dyr grundlæggende som generøse væsener der gerne giver sig selv til andre, men som samtidig forventer at modtage ækvivalente værdier. Dyr lader sig nedlægge; men nogle døde mennesker bliver til dyr, og ellers hjælper menneskelige shamaner arterne med at gendanne sig ved at udpege mennesker (typisk fra nabogrupper) der skal dø for at kompensere for dyrenes tab. Andre steder, bl.a. i det nordlige Canada, ses jagt som en form for ægteskabsudveksling hvor der gælder de samme gensidige forpligtelser imellem

34 Bourdieu: Le sens pratique (1980); Derrida: Donner le temps (1991); Donner la mort (1992); Godelier: L'Énigme du don (1996); Milbank: "Can a Gift be Given: Prolegomena to a Future Trinitarian Theology" (1995); jf. i dansk teologi: Bo Kristian Holm om gave-strukturen i Luthers Teologi. Og jf. Klostergaard Petersen 2016.

35 Til 'prædation' på dansk, jf. Lex.dk, "Prædation og parasitisme på dyr”. Ole Davidsen (2003) har foreslået at revitalisere ordet 'tægt' (som nu kun bruges i sammensætninger: 'selvtægt', 'varetægt') i kontrast til Mauss' gave. 
menneske og dyr som imellem menneskelige parter. Og australske, totemistiske, samfund er helt igennem bestemt af nødvendigheden af udveksling: af mennesker i undertiden meget komplekses slægtskabssystemer, bytte af fødevarer osv. ${ }^{36}$

Disse tre relationsformer er alle kompatible med animisme, og Descolas eksempler er alle primært hentet fra sydamerikanske lavlandskulturer med sammenlignelige økologiske og sociale forhold. Man kan altså ikke hævde at én af dem skulle være karakteristisk for animisme eller for jæger-samler-agerbrugs-kulturer. Forestillinger om at alle, eller alle vigtige, relationer 'i grunden' er gave, eller prædation, eller udveksling, kan tænkes i alle kulturer til alle tider. På den anden side giver de alle umiddelbart god mening netop i forhold til en animistisk ontologi. Men ingen af dem er specielt karakteristiske for samfund med en totemistisk, en analogistisk eller en naturalistisk ontologi. Altså må der også kunne tænkes andre relationsformer.

Hvis man i stedet for at begynde med ækvivalente termer begynder med termer der ikke er ækvivalente, hvor altså nogle er overordnede andre, vil der ifølge Descola også kunne tænkes tre mulige: frembringelse (produktion), beskyttelse (protektion) og overlevering (tradering, transmission).

Man kan mene at den afgørende relation er frembringelse. Den gammeltestamentlige forestilling om en guddom former mennesket af ler, er et eksempel på en frembringelses-relation inden for en analogistisk ontologi. Her vil en gensidighedsrelation ikke give mening. Skabningen kan nok svare på sin skabthed fx ved lovprisning af eller taknemmelighed over for Gud; men den kan i sagens natur ikke på samme måde forme stof og deraf skabe en skaber. Derimod kan den fortsætte skabelsen på deres eget plan, fx ved at skabe børn, eller kultur. Klassisk marxisme eller liberal industrialisme forstår også livsytringer fundamentalt som produktion, men funderet i en naturalistisk ontologi.

Relationen kan også overvejende være beskyttelse: En mere magtfuld aktør (fx en guddom eller et menneske: en konge, en hyrde) ser andre væsener som størrelser som er i ens varetægt og som skal beskyttes imod farer udefra eller indefra. En sådan relation vil være typisk for nomadesamfunds forståelse på deres hjorde. Beskyttelse kan kombineres med frembringelse, men behøver det ikke. Den babylonske kong Hammurabi så det som sin kald at beskytte sine undersåtter, uden direkte forbindelse med det ontiske spørgsmål om hvor de kom fra. Og nutidig naturbeskyttelse kan forbindes med fx en skabelsesteologi; men en naturalistisk ontologi vil oftest anses for rigelig begrundelse.

Endelig kan relationen være overlevering. Her vil det afgørende være at en ansvarlig aktør forstår sig selv som et led i en kæde af stationer hvor værdier overføres fra tidligere og mere prominente aktører til fremtidige og mindre prominente. Religioner hvor forfædrene (der typisk er irritable og krævende!) er særlig vigtige, er et eksempel. De

36 Disse tre relationer svarer påfaldende nok til tre grundformer for ægteskab som Dumézil (1979) kunne analysere frem i indisk og romersk kontekst, og som var en variation over de tre funktioner. Ægteskab kunne her være (1) en faders gave til en svigersøn; (2) en mands rov af en kvinde imod hendes faders vilje; (3) en handel hvor ægtemanden betalte faderen en symbolsk modydelse. 
leverer værdier, fx moralske forskrifter, eksempler til imitation og anden vigtig information, til nutiden med forventning om, at den leverer værdierne videre til eftertiden. En sådan tankegang blev vigtig i dele af GT, hvor forældre i Deuteronomium indskærpes pligten til at belære deres børn om den belæring (torah) som deres forældre fik overleveret fraJahve via Moses (Deut 4,9f.; 6,20-25). Overlevering kan kombineres med frembringelse og beskyttelse. Den skabende guddom kan således forvente af mennesker at de beskytter skaberværket og betragter det som betroet gods de kan bruge, men ikke eje. En sådan kombination virker nærliggende i en analogistisk ontologi som den gammeltestamentlige; men de naturalistiske eksempler viser at kombinationen ikke er nogen nødvendighed. Forskellen imellem frembringelse, beskyttelse og overlevering kan også beskrives som hhv. en genetisk, en spatial og en temporal relation: i frembringelse er der en direkte, stoflig relation; beskyttelsen gælder en given størrelse i rum; overleveringen gælder formidlingen af en størrelse i tid.

Descola $(2013,334)$ sammenfatter disse seks relationsformer i flg. skema:

\begin{tabular}{|l|l|l|l|}
\hline \multicolumn{2}{|c|}{ Ækvivalente termer } & \multicolumn{2}{c|}{ Ikke-ækvivalente termer } \\
\hline Symmetri & Udveksling & frembringelse & genetisk forbindelse \\
\hline Negativ asymmetri & Prædation & beskyttelse & spatial forbindelse \\
\hline Positiv asymmetri & Gave & overlevering & temporal forbindelse \\
\hline
\end{tabular}

Mens ækvivalente relationsformer fungerer godt i de tribale samfund hvor jagt er vigtig, kan de ikke-ækvivalente forekomme i alle slags samfund, inkl. jægersamfund. Ligesom mht. ontologierne, men i endnu større grad, skal relationsformerne forstås som muligheder hvor nogle typisk dominerer mens andre har en mere marginal eksistens. I den klassiske modernisme var frembringelse dominerende; en skov eller en dyreart var noget foreliggende som kunne avles og forbruges. I nutiden er produktionen trængt tilbage af beskyttelse og overlevering som dominerende handlingsprincipper, men fortsat oftest med naturalismen som basis-ontologi. Og animister kan forestille sig at dyr og planter beskyttes af en vildtets, skovens eller havets hersker, også når de ikke selv praktiserer en tilsvarende beskyttelse. Alle tre ikke-ækvivalente relationer kan fungere godt inden for en analogistisk ontologi, og de kan tænkes sammen. Men formentlig vil der altid være en af dem der vil dominere. Fx spiller frembringelse i GT ikke så stor en rolle som beskyttelse og overlevering der er centrale i hhv. den præstelige teologi og i 'enklave-teologien' (deuteronomismen).

Også denne analyse mener jeg er af stor relevans for religionsvidenskaben. Den kan $\mathrm{fx}$ dæmpe forventningerne til forståelsespotentialet $\mathrm{i}$ begrebet gave. I stedet for at se gaven som nøglen til fx socialitet eller religion overhovedet er det mere realistisk at se den som en ud af seks grundlæggende relationer og som en relation der kan have en særstatus i en kulturs ethos, men som ikke behøver at have det, og som ikke vinder $\mathrm{i}$ analytisk klarhed ved at blive enten sat som den dybeste hemmelighed eller (kynisk) 
reduceret til noget andet, fx til prædation eller udveksling. Og i øvrigt kan viden om kategorien prædation værne imod naiv idyllisering af animistiske grupper!

\section{Ontologier og religionsvidenskab}

Descolas analyse af de fire ontologier bør som sagt efter min mening være en del af de basale, religionsvidenskabelige beskrivelseskategorier, på linje med religionsfænomenologiske kategorier som myte og legende; ritual, offer og initiation; shaman, taumaturg og præst, religionshistoriske kategorier som tribal religion, arkaisk religion, aksialitet og postaksial religion, og religionssemiotiske begreber som indeksikale, ikoniske og symbolsk-arbitrære tegn. Derfor bør de også være obligatorisk del af den grundlæggende religionsvidenskabelige uddannelse. Heri ligger ikke en påstand om disse skemaer over ontologier og relationsformer skulle være immune over for kritik. Men en videnskab (og en uddannelse) kan ikke fungere uden et fælles inventar af beskrivelseskategorier, som indøves før de udsættes for kritik. Og kritikken er kun gyldig hvis den kan erstatte det kritiserede med et bedre alternativ. Descolas ontologier og relationsformer udfylder et hul i det eksisterende inventar af religionsvidenskabelige kategorier. Ud over de etablerede geografisk-historiske religionsformer (græsk religion, hinduisme, 'naturfolks religion' osv.) har religionsvidenskaben ladet sig nøje med de tværgående fænomenologiske kategorier og Clifford Geertz' overordnede tvedeling af alle religioners indhold i verdensbillede og ethos. Men religioner er uden tvivl også og frem for alt grundlæggende virkelighedsforståelser, eller de forudsætter sådanne. Her vil Geertz' kategorier ikke være tilstrækkelige, for de fokuserer (typisk 'etnografisk') på det der er unikt for den enkelte religion og indfanger ikke den (typisk 'antropologisk') har til fælles med andre religioner om hvad der antages at være eksisterende og meningsfuldt. ${ }^{37}$

Descolas model over ontologier er ikke i sig selv en historisk model og kan derfor ikke uden videre omsættes til historiske faser. Da ontologierne er aktiveringer af typiske mentale skemaer, er de sub- eller transhistoriske; alle mennesker til alle tider har i princippet evnen til at ræsonnere animistisk, totemistisk, analogistisk eller naturalistisk. Dertil kommer en måske typisk 'antropologistisk' armslængde til historien. Antropologen viser hvad der er tilfældet; det er op til andre at se hvilke skemaer der typisk aktiveres hvor, hvornår og hvorfor. På den anden side er der også i Descolas egen fremstilling historiske dimensioner. Det kan ikke ignoreres at naturalisme som dominerende ontologi er et produkt af den nyeste, oprindeligt 'vestlige', historie. Det er indlysende at totemisme og animisme som dominerende skemaer hører hjemme i ikke-statslige kulturer uden markant socialt hierarki, arbejdsdeling, bydannelse, bureaukratisk forvaltning og skriftsprog. Og endelig er det påfaldende at analogismen netop er dominerende fra og med de tidlige højkulturer og frem til moderniteten. Der er altså en første, omtrentlig parallel til Robert Bellahs hovedfaser i den religions- og

37 "[A]nthropology, it must be emphasized again and again, is not ethnography": Descola 2010, 212. 
kulturhistoriske evolution, fra tribale kulturer over arkaiske og postaksiale kulturer og frem til det moderne. En parallelisering vil så rejse mindst to spørgsmål: dels om hvor langt Descolas systematiske kategorier kan forbindes med Bellas historiske faser, dels om hvordan overgangen fra én ontologi til en anden kan forstås.

I et fascinerende kapitel i Beyond Nature and Culture (kap. 15: "Histories of structures", p. 365-390) viser Descola selv et tænkt eksempel på overgangen fra dominerende animisme til dominerende analogisme. Han sidestiller tre kulturer der alle henter en væsentlig del af deres føde fra rensdyr: dels jægere (Montagnais) fra det nordøstlige Canada, dels nordøstsibiriske jægere (Tjukter og andre), dels sibiriske nomadefolk længere imod syd (med Exirit-Bulagat som eksempel). De canadiske jægere har ikke domesticeret rensdyr. Tjukterne udøver semi-domesticering hvor rensdyrene går vildt en del af året og hentes ind og malkes en anden del af året, samtidig med at rensdyr er yndet jagtbytte. Exirit-Bulagat driver også rensdyrjagt, men som en bibeskæftigelse i forhold til flokke af heste og kvæg. Mens Montagnais får tilladelse til at nedlægge deres jagtbytte af en normalt venligt indstillet rensdyr-ånd, indgår Tjukter i et bytteforhold med rensdyrenes herre. Exirit-Bulagat derimod er underlagt en himmelsk guddom og forfædrene som styrer deres flokke af husdyr og til hvem de bringer ofre og til hvis uigennemskuelige vilje de er udleveret, samtidig med at deres jagtbytte er regeret af særlige ånder der er fordelt på steder i landskabet. Denne samstilling viser en gradvis transformation fra animisme (Montagnais) til analogisme (Exirit-Bulagat). En af pointerne her er at animisme giver god mening hvis et menneske står over for et bestemt, konkret dyr, som jægeren over for sit bytte, mens analogisme giver bedre mening hvis dyrene udgør en større mængde og mennesket er dets besidder; animismen er basalt set egalitær og horisontal, analogismen hierarkisk og vertikal. 'Transformationen' er ikke i sig selv historisk, men strukturel, og den kan sikkert i princippet gå i begge retninger. Men den overordnede kulturelle evolution har dog bestået i at komplekse og hierarkiske kulturer har dannet sig ud fra enklere og mere egalitære kulturer; hovedreglen må have været at animisme 'går forud for' analogisme.

Descolas eksempel er også tankevækkende fordi den analogistiske pol her ikke optages af en agerbrugskultur, men af kvægnomader. 'Den store mængde' af enkeltstørrelser som analogismen tilstræber at fatte og udtrykke, består her ikke i fx mange kornaks eller mange mennesker, men i mange domesticerede dyr. Agerbrug i sig selv lægger formentlig ikke op til analogisme. Jagt er nok en vigtig del af Amazon-kulturerne som fx Achuar; men den største del af føden kommer fra kvinders havedyrkning.

Et af de mest værdifulde træk i Descolas model over ontologier er at den giver plads til de tidlige højkulturer - der så ofte glemmes i modstillinger imellem antropologens nutid og antropologens eksotiske genstandsområde. Religionsvidenskabens forskningshistorie er domineret af etnografisk baserede antropologer, fra lænestolsantropologer som Tylor, Frazer, Durkheim og Mauss til feltarbejdsantropologer som Malinowski, Evans-Pritchard, Victor Turner og Clifford Geertz (strukturalister som LéviStrauss og Descola selv er undtagelser; her kombineres erfaring fra feltarbejde med 'lænestolen', dvs. med biblioteket). Importen fra antropologien ind i religionsvidenskaben har kastet meget godt af sig. Men det har også fremmet et teoriunderskud hvad 
angår arkaisk religion ${ }^{38}$ (jf. Lundager Jensen 2017) - paradoksalt fordi det netop er i disse religioner og ikke i de tribale at man finder de mest prototypiske eksempler på 'religion' i betydningen 'tro på guder og himmelske magter'.

Robert Bellahs begreb om 'arkaisk religion' har været et vigtigt middel til at udbedre denne paradoksale ubalance i religionsvidenskaben. Dette store religionshistoriske felt fremstår i første omgang som en uoverskuelig, broget mangfoldighed hvor alle de mange og dybtgående forskelle gjorde eventuelle ligheder til trivialiteter. Med 'arkaisk religion' var det nemmere at se også fundamentale ligheder, nemlig at de forudsatte en slags stat og var bygget op omkring forestillingen om et begrænset antal guddomme der havde etableret en kosmisk og social orden inde i et uformeligt kaos af mørke og/eller vand - en orden som de også beskyttede og administrerede fra deres himmelske udsigtspunkt og deres jordiske boliger.

Men i Bellahs skema er det nødvendigt at skelne imellem arkaisk religion og postarkaisk kompromis-religion. 'Verdensreligionerne', fra buddhismen til kristendommen, opstod som dannelser der byggede på en aksial afvisning af de værdier der var indiskutable i det arkaiske og med bud på radikale alternativer i form af forløsning fra den jordisk-ontiske orden overhovedet og frelse til en helt anden og lykkeligere ontisk virkelighed. Disse dannelser kunne imidlertid kun blive til levedygtige institutioner ved at reintegrere størstedelen af det arkaiskes værdier, inkl. himmelske magtvæsener, jordiske monumentale bygningsværker, præsteskaber, ritualer osv. Post-aksiale religioner kan også kaldes 'paradoks-religioner'. Tro imod deres oprindelse har de fastholdt at de tilsyneladende værdier er kortvarige og forbigående og derfor bør ignoreres. Men samtidig har de støttet op omkring de samme kortvarige værdier og hjulpet med alt det som tribale og arkaiske religioner kunne: befordre helbredelse, tryghed, velstand og stabile samfundsordninger. En fælles tankegang forbinder på mange måder arkaiske og post-aksiale religioner.

Analogismen kan altså ikke blot identificeres som en ontologi der ligger under arkaisk religion. Postaksiale religioner er mindst lige så analogistiske, og analogisme har været den dominerende ontologi op til midten af andet årtusind e.Kr. i Europa, indtil den langsomt blev erstattet af naturalismen, jf. ovenfor i artiklen her. Det efterlader et problem: Hvordan forstå det aksiale snit i forhold til de fire ontologier? Hvordan forstå en tankegang som ikke er interesseret $\mathrm{i}$ at forstå dyr, planter og alt det andet, verden består af, fordi det alt sammen hører til det der skal lægges bag en? Descola tangerer kun spørgsmålet i en kort passage i Beyond Nature and Culture. Her hedder det om analogistiske kollektiver at da alting hænger sammen, er der ingen isolerede, enkeltstående væsener:

Or if there are, it is by dint of extracting themselves utterly from those shared kinds of servitude and those endless hierarchies, as the 'renouncers' in India do and the One God 
Måske kan man her tale om en slags 'Nul-ontologi'; det ville ikke være paradoksalt hvis væren virkelig er intet. Men så langt går de fleste aksiale strømninger ikke. Selv om den kendte virkelighed flyttes over i det kaotiske (uvidenhedens og/eller syndens verden), vil der (måske bortset fra de mest konsekvente udgaver af buddhismen?) være væren nok tilbage til at rekonstruere en anden verden og analogistisk udstyre den med rum, tid, aktører, hierarkiske ordninger og skønhed - som i den kristne angelologis ni ordener af himmelvæsener hos senantikke / tidligt-middelalderlige teologer som Pseudo-Dionysios og Gregor den Store. Samtidig behøver den forladte virkelighed ikke kastes ned i et formløst kaos. Det kan retableres som en mørk, grim og ond anti-orden af dæmoniske magter, hierarkisk indordnet under en anti-hersker, forstået lige så vertikalt som den himmelske, men nedad, under jorden, som mylderet af dæmoner i Hieronymus Bosch' surrealistiske altertavler. Dualismer er allerede i deres anslag analogistiske. Og at modsætningerne forstås ikke som komplementære og harmoniske, men som antagonistiske og eksklusive, gør dem ikke mindre analogistiske.

Jeg foreslår altså følgende grove parallelisering imellem Bellahs faser og Descolas ontologier:

\begin{tabular}{|l|l|l|l|l|}
\hline tribal religion & $\begin{array}{l}\text { arkaisk reli- } \\
\text { gion }\end{array}$ & aksialt snit & $\begin{array}{l}\text { postaksial reli- } \\
\text { gion }\end{array}$ & $\begin{array}{l}\text { nutidsreli- } \\
\text { gion }\end{array}$ \\
\hline $\begin{array}{l}\text { animisme } \\
\text { totemisme }\end{array}$ & analogisme & naturalisme \\
\hline
\end{tabular}

Skemaet forudsiger med andre ord at hvis man har med en fx arkaisk religion at gøre, vil den formentlig vise sig at være baseret på en analogistisk ontologi; og hvis man har fx en gruppe mennesker hvis ontologi overvejende er animistisk, vil det vise sig at denne gruppe også har en tribal religion. Paralleliseringen er grov, for der er tribale kulturer (som i Descolas eksempel Exirit-Bulagat) der efter Bellahs kriterier vil høre til tribal religion, men hvor en analogistisk ontologi dominerer. Men Bellah selv medgav at selv om der er klare forskelle imellem en typisk tribal og en typisk arkaisk kultur, må de historiske overgange have været gradvise, og der har været tilstande hvor en præcis kategorisering ikke er mulig (fx Bellah 2011, 208f.). Det bør også gentages at der overalt er tale om dominerende tendenser. Alle ontologier kan i princippet forekomme i alle religionshistoriske faser. Et nutidsmenneske der er utvetydig naturalistisk i offentligheden, kan være analogistisk når hun indretter sit hjem efter feng shui-principper, totemistisk når hun besøger sine forældres gravsted, og animistisk når hun taler med sin hund (jf. Descola 2010a, 338). Tilsvarende med Bellahs faser: Verdensforsagere er ikke utænkelige i tribale, arkaiske eller nutidige samfund; tribale samfund kan have

39 Den vestlige pendant til indiske udstigere (jf. Religionsvidenskabeligt Tidsskrift 64, tema: Askese) er ganske vist ikke den ene guddom i GT, som tværtimod er gennemført analogistisk tænkt; et mere relevant eksempel vil være tidlig-kristne eremitter. 
guder, lige som nutidsmennesker kan; arkaisk religion kan have domineret i større byer, mens livet i landsbyer meget sandsynligt kan have opretholdt tribale forestillinger og ritualer.

\section{Sammenfatning: Descolas relevans for religionsvidenskaben}

Relevansen af Descolas teori eller model for religionsvidenskaben omfatter i hvert fald følgende punkter:

1. Den reaktiverer traditionelle og i princippet nyttige begreber som 'animisme' og 'totemisme' der var gået af brug pga. uhensigtsmæssige definitioner og uklar anvendelse. Her reaktiveres de ved at få en ny og mere præcis betydning.

2. Den opbryder modstillingen 'Vesten vs. Resten'- der er nogenlunde ensbetydende med 'modernitet vs. tradition', 'fornuft vs. irrationalitet', 'naturalismen vs. overtro', 'videnskab vs. religion'. 'Resten' kan ikke meningsfuldt sammenfattes under én kategori. Der er ikke én, men tre slags ikke-moderne, ikke-vestlige tankegange traditioner / former for irrationalitet / former for overtro / religioner.

3. Dermed differentieres også kategorien 'naturfolks religioner' (eller 'tribale religioner'). Der er ikke én, men tre hovedformer: animisme, totemisme og (tidlig) analogisme.

4. Dermed gøres det klart at der er lige så stor forskel imellem såkaldt 'naturfolks' virkelighedsforståelse (og dermed religion) på den ene side og de store oldtidskulturers virkelighedsforståelse (og altså religion) på den anden side, som den der består imellem hver af disse og naturalismen.

5. Dermed beskyttes også de tidlige højkulturers religioner imod forhastet at blive identificeret med 'naturfolks' religioner (som der er tendens til i klassisk religionsfænomenologi hos fx Mircea Eliade).

6. Da Descolas ontologier delvis lapper over med Bellahs historiske faser, suppleres disse der er funderet i politiske organisationsformer (før-statslige, mindre grupper, by- og territorialstater, imperier og transnational udveksling af mennesker, varer og ideer), med en fundering i kognitive strukturer. Bestemte politiske strukturer selekterer bestemte ontologier, ligesom bestemte ontologier kan fremme eller modarbejde bestemte politiske organisationsformer.

7. Ved at definere disse tre ikke-naturalistiske ontologier bidrager teorien desuden til at religionsvidenskaben selv - altså først og fremmest forskere, undervisere og studerende - bliver klarere i forståelsen af deres egen ontologi, 
inkl. hvor, hvornår og hvordan den er opstået, og hvilke uklarheder, dilemmaer og udfordringer den indeholder og bevirker. Naturalismen er nok den dominerende ontologi i nutidens vestlige verden. Men det vil være naivt derfor at tro at den skulle være ensbetydende med 'virkeligheden' (som allerede Frazer undertiden vidste). Den er en bestemt måde at kategorisere størrelser i verden med, som har vist sig uhyre effektiv på mange måder. Med naturalismen som fundament har mennesker kunnet uendeligt meget mere end mennesker med andre ontologier har kunnet. Prisen for denne kunnen - eller 'magt' - er så også blevet klar. Den har tjent menneskeheden som art, men på bekostning af mange andre arter. Med andre ontologier kunne mennesker meget mindre; til gengæld har andre arter kunne trives meget bedre.

\section{LITTERATUR}

Balée, William

2013 Cultural forests of the amazon: A historical ecology of people and their landscapes, University of Alabama Press.

Bellah, Robert N.

2011 Religion in Human Evolution. From the Paleolithic to the Axial Age, The Belgrave Press of Harvard University Press.

https://doi.org/10.4159/harvard.9780674063099

Brown, Peter

2003 The Rise of Western Christendom. Triumph and Diversity A.D. 200-1000, 2. ed. Blackwell.

Davidsen, Ole

2003 “Gave og tægt. Om udvekslingens centrale rolle i en semiotisk undersøgelse af de bærende betydningsstrukturer i urkristen religion/nytestamentlig teologi", Dansk Teologisk Tidsskrift 1, 32-52.

Descola, Philippe

1998 Spears of Twilight: Life and Death in the Amazon Jungle, The New Press.

2005 Par-delà nature et culture, Gallimard.

2010 "From Wholes to Collectives", in: Ton Otto \& Nils Bubandt, eds., Experiments in Holism: Theory and Practice in Contemporary Anthropology, Blackwell, 209-226. https://doi.org/10.1002/9781444324426.ch12

2010a "Cognition, Perception, and Worlding", Interdisciplinary Science Review, 334340. https://doi.org/10.1179/030801810X12772143410287

2011 L'écologie des autres. L'anthropologie et la question de la nature, Éditions Quæ. https://doi.org/10.3917/quae.desco.2011.01.0009

2013 Beyond Nature and Culture, oversat af Janet Lloyd, Chicago University Press. https://doi.org/10.7208/chicago/9780226145006.001.0001

2014 "Modes of Being and Forms of Predication", HAU: Journal of Ethnographic Theory, 271-280. https://doi.org/10.14318/hau4.1.012

Descola, Philippe \& Pierre Charbonnier 
2014 La composition des mondes, Flammarion.

Descola, Philippe \& Tim Ingold

2014 Etre au monde: Quelle expérience commune?, Presses universitaires de Lyon.

Désveaux, Emmanuel

1972 “Totémisme", in: Pierre Bonte \& Michel Izard, eds., Dictionnaire de l'ethnologie et de l'anthropologie, Presses Universitaires de France, 709-710.

Dumézil, Georges

1979 Marriages Indo-Européens, Payot.

Dupré, Louis

1993 Passage to Modernity, Yale University Press.

Durkheim, Émile

2000 Den sociologiske metodes regler, Hans Reitzel.

1895 Les regles de la méthode sociologique. Paris, 1895.

1996 "Représentations individuelles et représentations collectives", in: idem, Sociologie et philosophie, Quadrige / PUF, 1-48.

Fibiger, Marianne Qvortrup, et al.

2021 Andre Verdener. Indføring i religionshistorie og religionsfænomenologi, Univers (under publicering).

Flood, Gavin

1996 An Introduction to Hinduism, Cambridge University Press.

Frazer, James George

1922 The Golden Bough. A Study in Magic and Religion. Abridged edition, Macmillan (tilgængelig på Project Gutenberg). https://doi.org/10.1007/978-1-349-00400-3

Jett, Stephen C.

2017 Ancient Ocean Crossings: Reconsidering the Case for Contacts with the PreColumbian Americas, Alabama University Press, 2017.

Kelly, John D.

2014 "Introduction: The ontological turn in French philosophical anthropology", Hau: Journal of Ethnographic Theory, 4 (1), 259-269.

https://doi.org/10.14318/hau4.1.011

Klostergaard Petersen, Anders

2016 Gaven, Aarhus Universitetsforlag.

Kohn, Eduardo

2013 How Forests Think. Toward an Anthropology beyond the Human, University of California Press. https://doi.org/10.1525/9780520956865

Latour, Bruno

2006 Vi har aldrig været moderne, Hans Reitzel.

Lévi-Strauss, Claude

1964 Le Cru et le cuit, Plon.

Luckert, Karl

1975 The Navajo Hunter Tradition, The University of Oklahoma Press.

Lundager Jensen, Hans J. 
2016 “Ontologier i Det Gamle Testamente: analogisme og animisme (Gen 1 og 23)", Collegium Biblicum Årsskrift, 1-19.

2017 "James George Frazer: viktoriansk helt, 20.årh.s skurk, nutidig mediator", Religionsvidenskabeligt Tidsskrift 67, 77-104.

https://doi.org/10.7146/rt.v0i0.104622

2019 “Natur, Bibel, analogisme”, Fønix, 347-395.

2021 Religion og teologi i Det Gamle Testamente, Eksistensen.

Otzen, Benedict

2002 Tobit and Judith, Sheffield Academic Press.

Ovid

1989 Ovids forvandlinger, oversat af Otto Steen Due, Centrum.

Tylor, Edward Burnett

1871 Religion in Primitive Culture, Vol. 1, Cambridge University Press (tilgængelig på Archive.org).

Weber, Max

1920 Gesammelte Aufsätze zur Religionssoziologie, 1-3, J.C.B. Mohr (Paul Siebeck), reprint. 1988.

Hans J. Lundager Jensen, professor, dr.theol. Afdeling for Religionsvidenskab, Aarhus Universitet 